Article

\title{
Enhancing the Cultural Heritage through Adaptive Reuse. A Multicriteria Approach to Evaluate the Castello Visconteo in Cusago (Italy)
}

\author{
Marta Dell'Ovo ${ }^{1, * \mathbb{C}}$, Federico Dell'Anna ${ }^{2, * \mathbb{C}}$, Raffaella Simonelli ${ }^{3}$ and Leopoldo Sdino ${ }^{1}$ \\ 1 Department of Architecture, Built Environment and Construction Engineering (ABC), Politecnico di Milano, \\ via G. Ponzio, 31, 20133 Milan, Italy; leopoldo.sdino@polimi.it \\ 2 Interuniversity Department of Regional and Urban Studies and Planning, Politecnico di Torino, \\ Viale Mattioli 39, 10125 Turin, Italy \\ 3 TeCMArcH Laboratory, Department of Architecture and Urban Studies (DAStU), Politecnico di Milano, \\ Piazza Leonardo da Vinci, 26, 20133 Milan, Italy; raffaella.simonelli@polimi.it \\ * Correspondence: marta.dellovo@polimi.it (M.D.); federico.dellanna@polito.it (F.D.)
}

Citation: Dell'Ovo, M.; Dell'Anna, F.; Simonelli, R.; Sdino, L. Enhancing the Cultural Heritage through Adaptive Reuse. A Multicriteria Approach to Evaluate the Castello Visconteo in Cusago (Italy). Sustainability 2021, 13, 4440. https://doi.org/10.3390/ su13084440

Academic Editor: Asterios Bakolas

Received: 31 March 2021

Accepted: 12 April 2021

Published: 15 April 2021

Publisher's Note: MDPI stays neutral with regard to jurisdictional claims in published maps and institutional affiliations.

Copyright: (c) 2021 by the authors. Licensee MDPI, Basel, Switzerland. This article is an open access article distributed under the terms and conditions of the Creative Commons Attribution (CC BY) license (https:// creativecommons.org/licenses/by/ $4.0 /)$.

\begin{abstract}
Cultural heritage can play a strategic role in developing a sustainable built environment, contributing to the improvement of the economic, social, and environmental productivity of a city. Human activities are constantly affecting the quality of the environment and altering the ecosystems, which produce negative consequences also on human wellbeing. Within this context, it has been much discussed how cities and the built environment can counteract this process by supporting more sustainable development. Adaptive reuse is defined as "a process that changes a disused or ineffective item into a new item that can be used for a different purpose", which strongly triggers the sustainable development of cities. It can be recognized as a promoter of economic growth, social wellbeing, and environmental preservation, given its capability of both preserving past values and creating new ones. The adaptive reuse matches the main points of the circular economy, seen as the sustainable economy, which is aimed at the reduction of natural resource extraction and environmental impact by extending the useful life of materials and promoting recovery, reuse, and regeneration processes. Given these premises, the current contribution aimed to evaluate alternative scenarios for reuse in Castello Visconteo in Cusago, located in the Lombardy region (Italy), and understanding how adaptive reuse could contribute to generating new values within a circular economy perspective. In detail, four alternative scenarios were proposed to face the new needs born during the COVID-19 pandemic period. Since both intangible and tangible values must be considered, a multicriteria decision analysis (MCDA) has been applied by combining economic and qualitative indicators to define the most suitable function for its adaptive reuse. In detail, the Novel Approach to Imprecise Assessment and Decision Environments (NAIADE) was used to identify the best alternative solution based on the opinions of conflicting stakeholders. The innovativeness of the contribution is given by the combination of different methodologies, the preservation of the memory and the generation of new values, and the consideration of adaptive reuse as a strategy for the achievement of sustainable development within a circular economy perspective.
\end{abstract}

Keywords: adaptive reuse; cultural heritage; sustainable development; multicriteria decision analysis (MCDA); intangible values; COVID-19; Novel Approach to Imprecise Assessment and Decision Environments (NAIADE); stakeholder interaction; Simple Multi-Attribute Rating Technique Extended (SMARTER)

\section{Introduction}

The main problem that affects the heritage of cultural heritage today is represented by the phenomenon of buildings that have lost their original destination and are being abandoned in increasing numbers [1]. In the context of urban transformations, the reuse 
of existing heritage has attracted increasing interest in recent years, both in the face of the large availability of abandoned or underused properties and due to the need to identify new economic engines for urban areas that have lost their original function and their competitiveness [2-4]. The question that arises is whether there is the possibility of reuse, and if so, how can this end be pursued? The origin of this phenomenon was mainly due to the dizzying increase in the maintenance and management costs of properties for owners, public or private, and the increasingly limited funding from public bodies. Today, it represents one of the problems capable of igniting public opinion that is increasingly sensitive to the issues of the protection of historical and artistic heritage $[5,6]$. The protection of cultural heritage is not only of a conservative nature. Within the Italian urban and rural landscape, historic buildings have always represented important centers of aggregation and points of strong historical identity for the towns or urban districts that have developed around them [7-10]. The best strategy to preserve, and at the same time enhance, an abandoned historic building is undoubtedly to give it a new function in the perspective of adaptive reuse [11]. Adaptive reuse is defined as "a process that changes a disused or ineffective item into a new item that can be used for a different purpose" [12]. Adaptive reuse involves integrating maintenance, restoration, or reuse interventions by comparing and showing a new function to be compatible with the historical and architectural characteristics and with the structural properties of the buildings. One of the greatest difficulties is often linked to the fact that these structures have such dimensions as to be disproportionate to the surrounding building fabric, consequently making them difficult to manage from the design point of view. This issue is observed above all in small villages more than in the contexts of large cities. Another problem consists of identifying an intended use that is suitable for the historical, typological, and architectural characteristics of the building and which, at the same time, brings together all the actors involved, both public and private $[13,14]$. The intervention may also be further subject to limitations by the building regulations in force at the municipal level or by restrictions imposed by specific protection bodies. For this reason, it can be seen that it is not possible to identify a univocal way of operating that can be applied every time we find ourselves having to intervene on an abandoned cultural building $[15,16]$. Every single intervention needs an approach aimed at providing an optimal solution case by case, regardless of a careful analysis of the building, the surrounding context, and the actors involved in participating in the decision-making process.

In the last decade, cultural heritage has represented in the European debate one of the fundamental resources for sustainable development, capable of contributing to the economic growth of the territories in the circular economy perspective $[17,18]$. The role of cultural heritage is recognized in the United Nations 2030 Agenda for Sustainable Development and in particular in Goals 11 (development of inclusive, sustainable, safe, and resilient communities), 4 (education), and 8 (sustainable economic growth, such as cultural tourism) [19]. It is recognized that the conservation and reuse for new functions of the cultural and landscape heritage can have positive impacts on the quality of life and individual and community well-being, contributing to the creation of jobs, the conservation of natural resources, and the revitalization of cities hosting heritage [20-22]. Given these premises, adaptive reuse could be the answer to both preserving memory and generating new values, looking at a more holistic vision, i.e., integrating social, economic, environmental, urban, and political policies in agreement with the Sustainable Development Goals (SDGs) and providing additional benefits related to the economic value of the landscape where the asset is located $[23,24]$.

Adaptive reuse interventions of buildings of cultural interest are complex, both from an economic point of view, given the high risk of uncertainty and limited financial resources, and from a social point of view, given the identity of the assets. The risk is not linked only to the economic investment, but also to possible wrong choices of little use for the community $[25,26]$. For this reason, we need rigorous and transparent analyses, capable of identifying in advance the technical, procedural, and economic management obstacles. In this sense, the need arises for a study to support the decision with the primary objective 
of optimizing resources, allocating of scarce public resources, and maximizing the utility of society.

The involvement of the public and stakeholders in the decision-making process is increasingly widespread in planning activities, allowing approaches that are no longer technocratic but rather participatory. Despite this interest, few researchers have investigated models for considering stakeholders in adaptive reuse projects [27-29]. Starting from these considerations, one of the main goals of this work was to determine an evaluation model integrated into a process to support the design of complex projects considering actors involved with the intent to select the choice more appropriate in line to on-site and off-site impacts [30].

With this in mind, this study analyzed the exemplary case of the Castello Visconteo in Cusago, located in the territory of the Metropolitan City of Milan (Northern Italy). Refunctionalization projects revolving around functional destinations that need new spaces and new layouts dictated by the needs born in the pandemic period of COVID-19 have been defined. The main objective of the new scenarios is to provide services to reduce the pressure of the existing structures in the Metropolitan City. The purpose of this work was to define a methodological framework where the scenarios of adaptive reuse identified are evaluated by applying a compensatory approach which will result in a rank of suitability and will assess the opinion of experts and policymakers, detecting their coalition and conflict through the use of the Novel Approach to Imprecise Assessment and Decision Environments (NAIADE) [31,32]. The need to execute a decision-making model with NAIADE arises from the fact that the intervention in question is relevant for different actors interested in the building and its transformation. NAIADE seems a tool capable of supporting the decision-making process in the preliminary stages rigorously and transparently, which allows users to capture the interests of the actors and limit the possible conflicts that would arise. The application of the NAIADE method in this case allowed us to include the opinion of six experts with different backgrounds and to evaluate the degree of preference of the alternatives according to a nine-level scale. The alternative scenarios were also assessed through a "What if" sensitivity analysis supported by the Weighted Sum Model (WSM) and the Simple Multi-Attribute Rating Technique Extended (SMARTER) method. The WSM made it possible to calculate an aggregate value of the performance of the design alternatives according to a set of criteria based on the social, technological, economic, environmental, and political (STEEP) dimensions. The SMARTER method made it possible to calculate the importance of the criteria according to the expert panel and to rank the alternatives according to different points of view. The sensitivity analysis tested the degrees of credibility of the coalitions among the actors and verified the robustness of the model and the results obtained in order to formulate more solid recommendations for the decision maker (DM) [33].

The paper is structured as follows: Section 2 presents a review of the evaluation methods used in the context of adaptive reuse design, Section 3 describes the proposed framework to support complex decision-making processes in the built environment, Section 4 focuses on case study presentation, Section 5 presents the NAIADE model application on a real case study, Section 6 discusses the results of the application, conclusions follow in Section 7.

\section{Assessment of Cultural Heritage}

The reuse and the enhancement of cultural heritage involve the evaluation of multiple values and the consideration of the opinion of several stakeholders [34,35]. This urgency has led to the application of multi/multiple criteria decision making (MCDM) methods in order to support the DM to make a more conscious decision about a set of alternatives. In this context, the decision which the DM should make can have a strong impact on the building itself, but also on the place where it is located and on its community. In fact, the adaptive reuse of a building has both internal consequences, such as changes to the layout and costs related to renovation and installation works, and external consequences, 
depending on the context, such as the creation of new job opportunities and modification of the social perception of the assets. On-site and off-site effects could be both positive and negative and their impacts should be carefully evaluated in order to select the alternative which defines a satisfactory tradeoff among all the dimensions and stakeholders involved.

In order to define a suitable framework able to consider the most important values carried on by the cultural heritage, a literature review has been developed with the aim of investigating the criteria identified. This step consisted of searching on the database Scopus by selecting specific keywords and then evaluating the coherence of the paper. Based on the concept that cultural heritage deals with multiple criteria and that a multicriteria methodology should be adopted, the review considered the following keywords "MCDM" or "MCDA" or "MCA" and "Cultural Heritage". A total of 37 papers were found and after a screening developed by analyzing the title and the abstract, 14 papers were selected that were considered more pertinent to the aim of the research and referred to specific interventions rather than urban regeneration projects [28,36]. Appendix A presents the results of the literature review and the analysis that was carried out. It is possible to appreciate how together with the purpose of the contributions, the main focus is on the criteria defined by each paper and their division in hierarchical levels.

All the papers were interested in defining an evaluation framework to support DMs in defining the most suitable solution for adaptive reuse of heritage buildings, even if the value trees developed were different, with a unique exception, [9,13], where the contributions shared the same criteria. Despite the differences detected, it was possible to draw some common features, in fact, one aspect evaluated by most of the scholars was the compatibility of the function with the building $[9,13,17,37-42]$, which is both a historicalcultural and functional issue, and as a result will affect also the economic dimension. Also important is the recognizability of the asset and its preservation, which could also impact the image of the city $[17,33,38-41,43,44]$ where it is located and the perception of the community as an icon. What deserves to be investigated is also the quality of the spaces the new function will design, and in particular the recreational one that is promoted in order to activate the participation of citizens [9,13,17,27,33,37,38,40,42,44,45]. Moreover, on the side of the economic dimension, the current condition of the building has to be estimated in order to have a better idea about the initial cost and to assess its overall sustainability $[9,13,17,33,37,38,40,42,44]$. Generally speaking, it is important to frame an evaluation framework that is useful for the DM in order to make a decision, transparent in order to communicate the results to the citizens, and multidimensional in order to take into considerations the several aspects provided, tangible and intangible, and to ingrate the needs and expectations of the stakeholders involved.

\section{Methodological Approach}

Given these premises, this contribution aimed at defining a methodological framework where the scenarios of adaptive reuse identified are evaluated by applying a compensatory approach, which will result in a rank of suitability and will assess the opinion of experts and policymakers, detecting their coalition and conflict through the use of the NAIADE. Experts did not have direct relations with the case study under analysis and were not involved or interested in its transformation, but had specific and coherent knowledge about the problem investigated, while the policymakers were directly related to the case study under analysis.

By taking as reference Simon's model [46], the methodological approach was divided into three different phases (Figure 1).

According to the three stages presented, (intelligence phase, design phase, and decision phase), the approach has been developed in order to guide the DM from the first moment of the decision-making process until the validation of the results through the sensitivity analysis. 


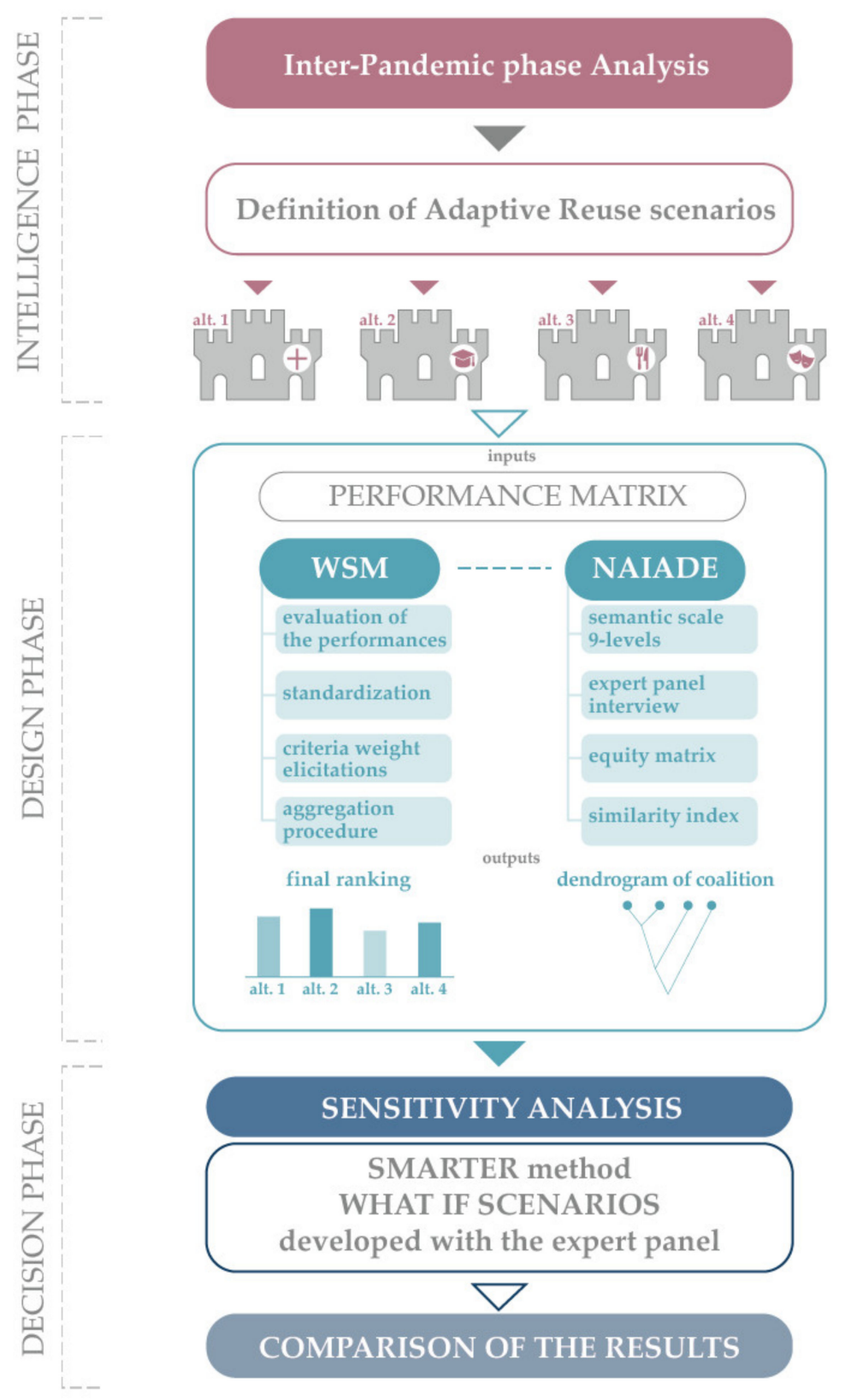

Figure 1. Methodological flowchart (where WSM: Weighted Sum Model; NAIADE: Novel Approach to Imprecise Assessment and Decision Environments; SMARTER: Simple Multi-Attribute Rating Technique Extended).

\subsection{Intelligence Phase}

Within this preliminary step, the current context and conditions that people worldwide are facing due to the pandemic situation caused by COVID-19 was investigated. Without going too much in depth about the reasons for the economic crisis that specific sectors are living in, and by considering the Italian context, where the case study is located, main issues have been recognized and criticalities detected. In detail, four different scenarios have been developed and will be further discussed in the fifth section. These alternatives have all been defined with the aim of promoting the local economy within a circular economy perspective and at the same time preserving the identity of the cultural heritage. Circular economy, which is conceived as the maximization of the traditional and linear flow through the material reuse, the use of renewable energy, the assessment of the value chain, etc. within the context of sustainable development considers the contribution of three dimensions (social, economic, and environmental) [47]. 


\subsection{Design Phase}

Once the alternatives had been defined, the evaluation was carried out in a twofold process. First of all, the value tree aimed at assessing the performances of the alternatives was defined by taking as reference the literature previously presented (Appendix A) and evaluating the frequency and the coherence of the criteria with the case study analyzed within this research. Since the project will have an impact both on the building and on the context, the evaluation framework was divided into two main dimensions, on-site and off-site, and then further classified considering the aspects of the STEEP analysis, i.e., social, technological, economic, environmental, and political.

Usually, the STEEP analysis is applied to determine which factor can influence a project, which strategy should be implemented, and which impact will be generated [48], and in this context, it was also useful to detect how much each alternative would satisfy the dimensions involved and evaluate their important for the decision about the adaptive reuse process. The prediction of both internal and external consequences is innovative within the context of the adaptive reuse but could be strategic in the perspective of the circular economy, where one of the main focuses is also the promotion of the local economy.

Table 1 presents the final evaluation framework defined as a result of the literature review. In addition to the criteria, the unit of measurement has also been specified (U.M), together with the indication of cost (a performance that has to be minimized, the lower the better) or benefit (a performance that has to be maximized, the higher the better) and a description about the meaning and how the criteria have to be measured. Within the framework, both qualitative and quantitative measures have been used and multidimensional aspects identified.

Table 1. Evaluation framework.

\begin{tabular}{|c|c|c|c|c|c|c|}
\hline Impacts & & Criteria & U.M & $(B / C)$ & Description & Source \\
\hline \multirow{5}{*}{ ON-SITE } & $\mathrm{S}$ & $\begin{array}{l}\text { Design of public } \\
\text { recreational spaces }\end{array}$ & sqm & B & $\begin{array}{l}\text { Creation of public space to promote } \\
\text { the social inclusion }\end{array}$ & {$[27,33,40,44]$} \\
\hline & $\mathrm{T}$ & $\begin{array}{l}\text { Compatibility of the } \\
\text { function with the } \\
\text { property }\end{array}$ & $\begin{array}{l}\text { scale } \\
(1-5)\end{array}$ & B & $\begin{array}{l}\text { How the new function will change the } \\
\text { internal layout and the image of the } \\
\text { asset [49] } \\
\text { (5) conservation and refurbishment } \\
\text { (4) rehabilitation and refurbishment } \\
\text { (3) renovations and refurbishment } \\
\text { (2) remodeling and refurbishment } \\
\text { (1) restoration and refurbishment }\end{array}$ & $\begin{array}{l}{[9,13,17,33,37-} \\
\quad 42,45]\end{array}$ \\
\hline & $\mathrm{E}$ & Initial cost & $€ /$ sqm & $\mathrm{C}$ & $\begin{array}{l}\text { Investment value for the restoration } \\
\text { and the installation of the new function }\end{array}$ & $\begin{array}{c}{[9,13,33,37,38,40} \\
42,44]\end{array}$ \\
\hline & $\mathrm{E}$ & $\begin{array}{c}\text { Construction periods } \\
\text { of building's } \\
\text { adaptation }\end{array}$ & months & $\mathrm{C}$ & $\begin{array}{l}\text { Months needed for the implementation } \\
\text { of the adaptive reuse project }\end{array}$ & {$[40,43]$} \\
\hline & $\mathrm{P}$ & $\begin{array}{l}\text { Involvement of local } \\
\text { associations }\end{array}$ & binary & B & $\begin{array}{l}\text { Creation of spaces to assign to local } \\
\text { associations that work in the territory }\end{array}$ & {$[17,27,39,44]$} \\
\hline \multirow{2}{*}{ OFF-SITE } & $\mathrm{S}$ & Catchment area & $\begin{array}{l}\text { scale } \\
(1-3)\end{array}$ & B & $\begin{array}{l}\text { Relevance of the project on the local (1), } \\
\text { regional (2), or national scale (3) }\end{array}$ & {$[17,38,40,41]$} \\
\hline & $\mathrm{T}$ & $\begin{array}{l}\text { Improvement of the } \\
\text { accessibility }\end{array}$ & binary & B & Integration of new transport systems & $\begin{array}{c}{[9,13,33,37,38,40-} \\
42,44,45]\end{array}$ \\
\hline
\end{tabular}


Table 1. Cont.

\begin{tabular}{ccccccc}
\hline Impacts & Criteria & U.M & (B/C) & Description & Source \\
\hline & S & Catchment area & $\begin{array}{c}\text { scale } \\
(1-3)\end{array}$ & B & $\begin{array}{c}\text { Relevance of the project on the local }(1), \\
\text { regional (2), or national scale }(3)\end{array}$ & {$[17,38,40,41]$} \\
OFF-SITE & E & $\begin{array}{c}\text { Mixed new job } \\
\text { opportunities }\end{array}$ & No & B & Diversification of job opportunities & {$[17,39,40,44,45,50]$} \\
\cline { 2 - 8 } & E & $\begin{array}{c}\text { Sustainable } \\
\text { Development Goals } \\
\text { (SDGs) }\end{array}$ & No & B & $\begin{array}{c}\text { SDGs satisfied from the development } \\
\text { of the adaptive reuse project }\end{array}$ & {$[9,13,37,38,40,42$,} \\
P & $\begin{array}{c}\text { Involvement of the } \\
\text { community }\end{array}$ & $\begin{array}{c}\text { scale } \\
(1-3)\end{array}$ & B & Age groups satisfied by the adaptive & reuse project & {$[17,27,33,39,40,44]$} \\
\hline
\end{tabular}

Once the evaluation framework has been defined, the elaboration can start, e.g., the twofold process. As it is represented in Figure 1, two multicriteria approaches have been applied in order to assess the suitability of the adaptive reuse scenarios. A compensatory method has been selected, since no thresholds or requirements have been specified and since it is important to identify the alternative able to define a satisfactory tradeoff among the dimensions involved. The analysis developed follows the main step of the MCDA, which consists in [51,52]:

- Evaluation of the performances of the alternatives measured by considering the unit of measurement defined and the description provided with the aim of obtaining a performance matrix.

- Standardization of the scores in order to make all the criteria comparable. Performances are standardized considering an a-dimensional scale (0-1) where 1 represents the best value, while 0 the worst, and the method applied is the maximum one which takes as references the Equations (1) and (2):

$$
\begin{aligned}
& \text { Benefit criterion : } \frac{\text { score }}{\text { highest score }} \\
& \text { Cost criterion }:-\frac{\text { score }}{\text { highest score }}+1 .
\end{aligned}
$$

- Criteria weight elicitations, which allow users to assign a different level of importance to the criteria defined within the evaluation framework. Within the design phase, it has been carried out by performing a neutral scenario where all the criteria involved were weighted with the same importance in order to avoid assigning a higher influence on some of the aspects defined in the framework.

- Aggregation of procedure results in the final suitability ranks, where alternatives are evaluated by considering their level of satisfaction with the objectives stated. The Weighted Sum Model (WSM) has been selected, which consists of summing up the yield values obtained by multiplying the score standardized of each criterion by the related weight assigned. The final value obtained represents the suitability of the alternative in the final rank [53].

The second part of the design phase concerned the application of the NAIADE (Novel Approach to Imprecise Assessment and Decision Environments), a discrete method developed by Munda [31,32]. This approach allows users to evaluate the alternatives starting from a performance matrix considering a technical solution and consider the opinions of stakeholders involved in the decision problem. This outranking method is suitable for solving complex projects since it allows users to order the alternatives defined, allowing at the same time, and as opposed to the additive method, individual pairs of scenarios to remain uncompared if there is no sufficient information to evaluate them [54]. The novelty, contrary to other fuzzy multicriteria methods, is given by the use of semantic distance to overcome weakness of traditional comparison methods. Moreover, it generates a rank 
of alternatives based on pairwise comparison techniques instead of a weighing system, like traditional discrete methods. By considering the description provided by [31,32], the application is mainly divided in four steps, namely (i) completion of the impact matrix, (ii) pairwise comparison of alternatives, (iii) aggregation of the criteria, and (iv) ranking of alternatives. (i) For what concerns the impact matrix, scores are assigned in the form of pure numbers or by considering the quantitative definition, which could be affected by uncertainty (e.g., fuzzy uncertainty). (ii) The comparison is developed by the introduction of semantic distance in the case of fuzzy or stochastic evaluations, which supports in measuring the distance between two functions. Moreover, the comparison is based on preference relations elicited by users. (iii) The aggregation is obtained by starting from the elaboration previously explained and calculating a preference intensity index of one alternative over the other. (iv) The indexes resulting from the aggregation allow the user to visualize a final ranking.

Beyond the technical compromise solutions, NAIADE facilitates also the social dimension by detecting coalition and conflicts among various interest groups, who are asked to elicit their opinion about the alternatives under evaluation by the use of a semantic scale [32]. In this case, an equity matrix is computed and based on the same concept of semantic distance, a similarity index is calculated for each pair of actors $i, j$. This elaboration allows the visualization of the dendrogram of coalition, able to show values of similarity index and levels of conflicts. The index is calculated with the following Equation (3):

$$
s_{i j}=\frac{1}{\left(1+d_{i j}\right)}
$$

where $d_{i j}$ represents the Minkowsky distance between group $i$ and group $j$ [55].

This phase allows the social conflict analysis and was the one developed within this contribution since the ranking of criteria has been carried out by applying a compensatory method.

\subsection{Decision Phase}

While in the previous phase, a neutral scenario has been visualized, in order to check the internal robustness of the final rank and to validate the result obtained, a sensitivity analysis has been performed, as well as a detailed "What if" analysis, which allows users to present different scenarios by changing the level of importance of the criteria. This phase has been developed by applying the SMARTER (Simple Multi-Attribute Rating Technique Extended) method [56], a simplified version of the SMART [57], where the DM is asked to rank the criteria from the most to the list important, requiring in this way a low effort, and the weights are assigned according to the Rank Order Distribution method (ROD). The application becomes complex when a higher number of criteria are involved, but given the limited number defined here (10), it was possible to proceed with its selection. The weights were assigned by the same stakeholders interviewed in the previous phase within the social conflict analysis to understand how the results are sensitive to changes and how they can be influenced by the opinions of different actors. With this overall picture, the DM is able to make a more conscious decision about the most suitable adaptive reuse scenario which should also be the one able to satisfy the highest number of stakeholders.

\section{Case Study}

The methodological approach was tested on a case study in order to evaluate its effectiveness and relevance.

The Castello Visconteo in Cusago, which has been in a state of poor condition (excluding the restoration and consolidation work recently carried out on the roofs of the south wing and on the tower by the owners and aimed at securing the property) and abandonment for about thirty years [58], is well suited to this type of analysis as it has been, in recent times, the subject of a series of reflections related to its enhancement.

As it is well known, this purpose is achievable only through the identification of functions compatible with the building, which are well suited to its material consistency 
and the state of preservation in which it is [59]. In fact, it is not possible, today, to foresee restoration interventions that are not part of an overall project capable of making the asset usable again $[60,61]$.

The castle, privately owned, is a landmark in the southern territory of Milan (Figure 2) and it is, specifically for the Municipality of Cusago, an important element and a focal point [62].

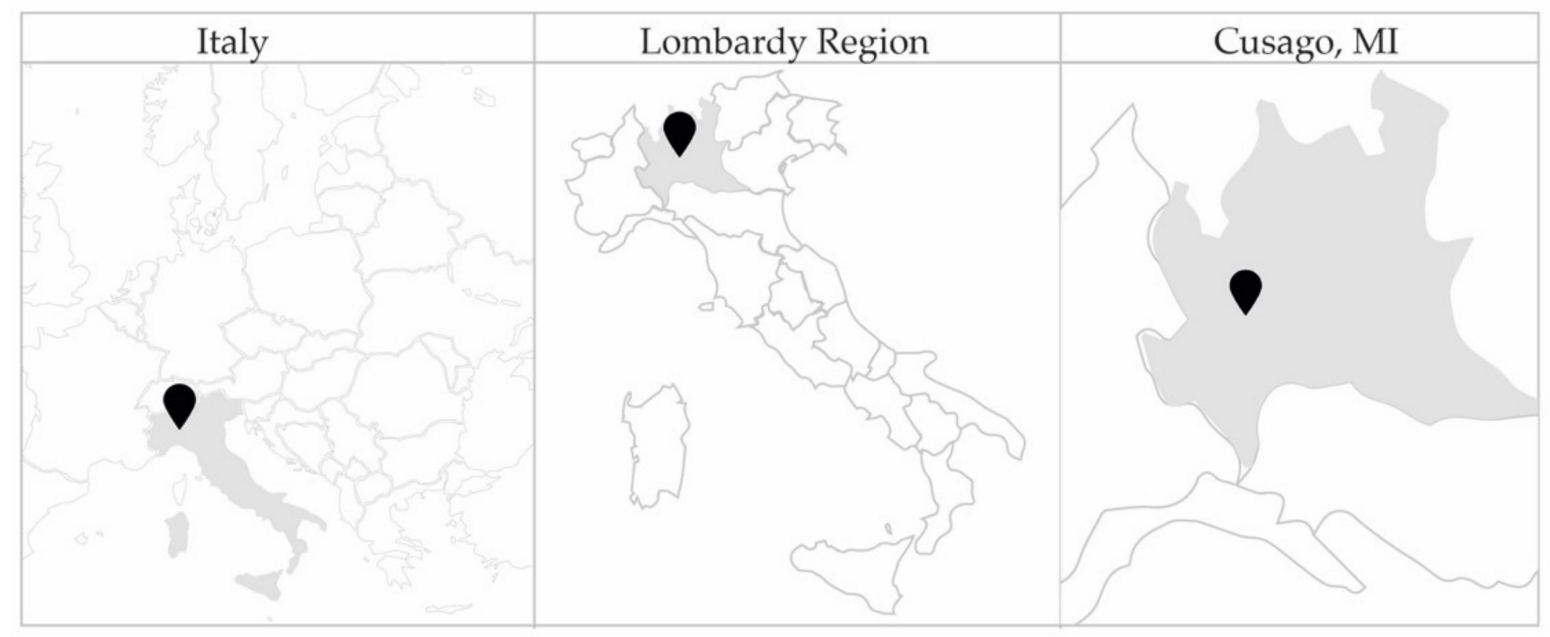

Figure 2. Location of the case study.

Bound by Legislative Decree 42/2004 ex L. 1039/39, it is part of a network of castles located between the Metropolitan City of Milan (southern part) and the Province of Pavia and it belongs to a project entitled "Castles of the Ancient Duchy of Milan: traveling on the water's edge" (Castelli dell'Antico Ducato di Milano: viaggiare a pelo d'acqua), which involves local governments and supports bodies with the aim of enhancing the heritage, through the promotion of cultural, artistic, tourist, social, and economic initiatives [63]. The project has been founded by Fondazione di Comunità Milano in June 2020 and among the actors involved there are Consorzio dei Comuni dei Navigli, Politecnico di Milano, DAStU - Lab TeCMArcH and Banca del Tempo di Cusago. Within this context we refer to the castles of Milan, Cusago, Abbiategrasso, Vigevano, Bereguardo, Pavia, and Binasco; they are seven castles (six of which are public) with their territories, located within two regional parks (Parco Agricolo Sud Milano and Parco del Ticino) and along three navigable artificial waterways (Naviglio Grande, Naviglio di Bereguardo, and Naviglio Pavese).

The castle in Cusago, built starting from the second half of the XIV century on the ruins of a Longobard fortification as a hunting residence of the Dukes of Milan and subsequently modified over the years, looks like a quadrangular structure with two floors, with masonry facades with plaster in geometric shapes partly still visible today, marked by low and pointed arch windows. The main façade, located on the east side towards piazza Soncino along the street to Cusago di sotto, presents a big tower in correspondence with the entrance, modified and raised during the XVI century. The internal facades, which overlook the large courtyard, are also characterized by plaster and pointed openings and, on the eastern side, there is a portico with round arches on columns. The perimeter masonry structures appear to be in fairly good condition from a static point of view but present a series of phenomena of degradation of the materials (there are widespread phenomena of rising damp, also due to the presence of an irrigation ditch flowing nearby, resulting in deep erosion of bricks and mortar joints, and extensive cement patches). They show, in general, numerous visible traces of plugging openings, modifications, and added bodies, related to the different uses of the spaces over time.

The interiors are very interesting and have different levels of degradation and disruption, aggravated by incompatible uses and abandonment that has lasted for decades. 
The castle is historically linked to illustrious figures who lived there over the years (among the many, Filippo Maria Visconti, who also built the Naviglietto, a branch of the Naviglio Grande from Gaggiano to Cusago, Ludovico il Moro, and Beatrice d'Este, the Casati Stampa family) and it has been a hunting lodge, lazaret, country mansion, and place of representation. In the eighteenth century, some rooms on the ground floor were used for silkworm breeding and other activities related to the agricultural sector, after World War II, it became a large "farmhouse" inhabited by about 30 families left without accommodation, and later even hosted a restaurant.

Numerous changes of ownership that, to date, have not had the strength to implement significant projects for the castle and the territorial context.

The local community and the municipal administration have always taken care of the castle, and in recent years they have tried to think in this direction through a series of ideas and proposals that will, in the short- and medium-term, give rise to interventions for the enhancement and reuse of the property, necessary for its effective preservation and transmission to the future (we mention, in this regard, a framework agreement signed since 2016 between the City of Cusago and the Polytechnic of Milan, DAStU Department, TeCMArcH Laboratory, entitled "Conservation of the built environment and cultural landscape in the territory of Cusago").

\section{Assessing the Adaptive Reuse}

\subsection{Alternative Scenarios}

From an economic point of view, the COVID-19 pandemic has had unprecedented effects in various economic sectors. The scenarios proposed in this study propose to reuse the Castello Visconteo in Cusago in a circular economy manner to recover the existing building and promote the local economy. The scenarios arose from a response to consumer demand and supplier offers. Based on analysis of Italian newspapers and repost of associations, the sectors most damaged by the pandemic emergency are the nursing home, education, recreational, and cultural sectors. In the following paragraphs, the project ideas that arose after a focus group of experts in various sectors will be presented.

Focusing attention on the evaluation presented here, it should be specified that, for now, four macro-functions have been identified at an indicative level as instrumental to the verification of the method. Given the specific objectives of the research, we have, to some extent, reversed the order that usually regulates the intervention on the existing building. These functions, or others to be defined, in order to become operational, require further analysis and refinements able to identify the whole set of destinations of use, "suggested" by the asset itself, able to trigger the "rebirth" of the castle in a systemic perspective, with effects on the wider scale of the territory [64]. In this sense, it is important to underline how the methodology described represents a starting point for broader reasoning that requires multidisciplinary studies and the involvement of many interested parties.

The correct procedure for the identification of appropriate functions compatible with the existing provides an approach that, starting from surveys and detailed readings [65], guides designers in understanding what are the real needs of the asset in relation to the context of reference [66], identifying, as regards the architecture, what we can call degrees of constraint and freedom from which to descend correct hypotheses of reuse. These analyses are therefore essential and constitute the cognitive/interpretative background from which to operate.

Another element to point out is that the functions identified so far (or other hypothetical ones to be evaluated) are not mutually exclusive but, on the contrary, could coexist in the castle, adapting to its conformation, size, and consistency, thus emphasizing its historical role.

Therefore, the evaluation methodology presented here in an "experimental" form may one day be used to verify whether the destinations formulated based on the studies mentioned above are compatible with the building and in line with the needs/requests that have emerged at various levels. 


\subsubsection{Nursing Home}

The management of the COVID-19 health emergency presented situations of vulnerability on which it was necessary to focus attention at all decision-making levels. The nursing homes concentrate the elderly and vulnerable population within them and during the pandemic, they had to offer a condition of health protection to limit the infection. Newspapers have made it known that in some Italian regions they have been more exposed to contagion, particularly in Lombardy, and have highlighted the criticality of these places. Based on a survey developed by the Italian Istituto Superiore di Sanità (technical-scientific body of the National Health Service) for nursing homes, the main difficulties encountered during the coronavirus epidemic were the lack of personal protective equipment, the inability to perform swabs, the absence of health personnel, and the difficulty in isolating people living with COVID-19 [67]. Referring to this last criticality, the "nursing home" reuse scenario envisages a public facility in line with the post-COVID-19 era, guaranteeing functional, typological, spatial, and morphological requirements designed according to new architectural criteria. The proposed design is represented by the concept of modules, which can be combined and adapted to the diversification of needs $[68,69]$. The modules also ensure good internal organization flexibility. The organization by nuclei provides the advantage of gathering groups of different guests in the same structure, while at the same time it is useful for creating opportunities for socialization within the nucleus. Given the large covered spaces available, the Castello Visconteo seems suitable for the incorporation of an accommodation facility, guaranteeing a subdivision of the spaces dedicated to different functions: living area, service areas for the community, health services, and general services. In addition, the large internal courtyard can guarantee ample space for guests to walk around in the safety of the building's perimeter walls. Furthermore, the strategic location in the rural context of Cusago and the immediate vicinity of Milan would guarantee a peaceful atmosphere without giving up the services offered by the city. Moreover, since more than $92 \%$ of Lombardy's nursing home structures are private entities, such as foundations, nonprofit organizations, and companies, so a new public facility can allow the most vulnerable and needy people to be accommodated.

\subsubsection{University Research Center}

Following the COVID-19 emergency, all over the Italian national territory, face-to-face educational activities relating to the current school year in the educational services for children and schools of all levels, as well as in universities, have been suspended. At the same time, distance learning was activated in the closing period linked to the coronavirus emergency. To support education, new communication platforms with new tools have been introduced. Besides, the public network Radiotelevisione Italiana (RAI), supported by the Italian Ministry of Education, has set up a new television schedule with new channels and new content with didactic and educational value, with different sections for subject and topics, so that they can be easily accessible and usable by teachers and students [70]. For the 2020/2021 school year, various provisions have been introduced to ensure the safe resumption of teaching activities in person, in compliance with safety regulations. However, the increase in infections and the entry of new variants of COVID-19 at the beginning of 2021 led again to the closure of school and university classrooms. Distance learning, therefore, seems to be the most suitable solution for dealing with diffusion and guaranteeing the right to education. In addition to theoretical courses, some university courses require laboratory activities where learning implies active participation and experimentation. From this perspective, the "university research center" scenario proposes to re-functionalize the Castello Visconteo as a pole of the faculties in the field of agricultural, forestry, and agri-food sciences of the Università degli Studi di Milano [71]. The new university center would house a library, canteen, and all the research facilities, from greenhouses to technical laboratories, necessary for carrying out the various training activities. The rural context in which the building is located is well suited to meet the needs of the courses of study of the 
faculties, thanks to the wide availability of covered open spaces and the numerous hectares of land that could be rented around to practice cultivation.

\subsubsection{Food District}

One of the sectors most affected by the current health crisis is HORECA (hotel, restaurant, café/catering). Fipe-Confcommercio (Federazione Italiana dei Pubblici esercizi) analyzed the employment levels in 2020, concluding that bars, restaurants, discos, and catering and banqueting companies lost 243,000 employees compared to 2019 [72]. The restrictions envisaged during the pandemic period by the Italian government on the opening hours of bars and restaurants have led to radical changes in the habits of business managers, which inevitably resulted in changes in the lifestyle of consumers. There are several precautionary measures envisaged for this sector, which entail organizational complications and high management costs for the owners of the catering businesses. Besides, the refreshments and measures to support the sector were insufficient. This situation has led many entrepreneurs to the idea of not reopening their business. Other entrepreneurs have opted for digitalization of the sector to stop losses and keep relationships with customers alive through food delivery. The future for the sector is very uncertain, but alternative solutions are possible to readjust tradition to new business systems in line with the new needs born in the pandemic period. The "food district" scenario proposes the creation of a food and wine center that aims to help small producers to promote local products. The basic idea is to create a center for the dissemination of food knowledge through modular conference rooms, rooms for cooking shows, refreshments, sales points, and urban orchards.

\subsubsection{Cultural Center}

Since the first days of the global emergency from COVID-19, the Italian government has legislated the closure of cinemas, theaters, live entertainment venues, and theme parks. The situation did not improve in the months in which the emergency seemed under control, and in which a gradual return to normality was rethought. In this phase, cinemas and theaters were reopened with a significant reduction in the number of people admitted to their recreational facilities. All this has led to serious losses for the entertainment sector with heavy repercussions also on employment levels. A new normal requires resilience and the ability to reinvent oneself from both an architectural and managerial point of view. Carrying out outdoor activities represent one of the key points to combat COVID-19 according to the Il Sole 24 study [73]. Secondly, in a sector where the activities foresee an hourly turnover of users, good management can guarantee an efficient and safe community service. For services with hourly programming, such as cinemas and theaters, it will be necessary to review the price list according to the daily bands and focus on personalized offers. With this in mind, the "cultural center" scenario aims to transform the building into a space set up not only for the provision of recreational services. The close collaboration with some social cooperatives and associations would allow the facility to meet the needs of subjects of various age groups. Furthermore, an auditorium will be dedicated to the setting up of permanent and temporary exhibitions hosting local creatives and artists. By considering the project entitled "Castles of the Ancient Duchy of Milan: traveling on the water's edge", there will also be an information center.

\section{2. $M C D A$}

\subsubsection{Performance Matrix}

Starting from the evaluation criteria (Table 1), the four scenarios have been analyzed and evaluated by considering the unit of measurement previously defined. Table 2 presents the performance matrix where the scores of each alternative are assessed. 
Table 2. Performance matrix.

\begin{tabular}{|c|c|c|c|c|c|c|c|}
\hline \multirow[b]{2}{*}{ Impacts } & & \multirow[b]{2}{*}{ Criteria } & \multirow[b]{2}{*}{ U.M } & \multicolumn{4}{|c|}{ Alternatives } \\
\hline & & & & $\begin{array}{l}\text { Nursing } \\
\text { Home }\end{array}$ & $\begin{array}{c}\text { University } \\
\text { Research } \\
\text { Center }\end{array}$ & Food District & $\begin{array}{l}\text { Cultural } \\
\text { Center }\end{array}$ \\
\hline \multirow{5}{*}{ ON-SITE } & $\mathrm{S}$ & $\begin{array}{l}\text { Design of public } \\
\text { recreational spaces }\end{array}$ & sqm & 0 & 1100 & 2850 & 2850 \\
\hline & $\mathrm{T}$ & $\begin{array}{l}\text { Compatibility of the } \\
\text { function with the property }\end{array}$ & scale $(1-5)$ & 2 & 3 & 4 & 5 \\
\hline & $\mathrm{E}$ & Initial cost & $€ /$ sqm & $2372.28 €$ & $2870.61 €$ & $2369.02 €$ & $1775.72 €$ \\
\hline & $\mathrm{E}$ & $\begin{array}{l}\text { Construction periods of } \\
\text { building's adaptation }\end{array}$ & months & 25,5 & 28 & 22,5 & 23,5 \\
\hline & $\mathrm{P}$ & $\begin{array}{l}\text { Involvement of local } \\
\text { associations }\end{array}$ & binary & no & yes & yes & yes \\
\hline \multirow{5}{*}{ OFF-SITE } & $S$ & Catchment area & scale $(1-3)$ & 2 & 3 & 2 & 2 \\
\hline & $\mathrm{T}$ & $\begin{array}{l}\text { Improvement of the } \\
\text { accessibility }\end{array}$ & binary & no & yes & no & no \\
\hline & $\mathrm{E}$ & $\begin{array}{l}\text { Mixed new job } \\
\text { opportunities }\end{array}$ & No & 2 & 4 & 2 & 1 \\
\hline & $\mathrm{E}$ & $\begin{array}{c}\text { Sustainable Development } \\
\text { Goals (SDGs) }\end{array}$ & No & 4 & 6 & 5 & 4 \\
\hline & $\mathrm{P}$ & $\begin{array}{l}\text { Involvement of the } \\
\text { community }\end{array}$ & scale $(1-3)$ & 1 & 2 & 3 & 3 \\
\hline
\end{tabular}

Within the on-site evaluation, factors of which directly affect the building, what relates to the Design of Public Recreational Spaces criterion in the nursing home is a function that requires a high level of privacy, however there are no areas devoted for this activity. Meanwhile, for the university research center", half of the internal courtyard, and for both the food district and the cultural center, the whole courtyard and the one floor of one of the wings would be suitable. Compatibility refers to the level of intervention necessary to make the building suitable to host the function [49], the higher or lower the score corresponds to the degree of changes. Given the complexity associated with the spaces and the installation system required for the nursing home (2) and the university research center (3), they both obtained a lower score compared to the food district" (4) and the cultural center" (5), which already could be hosted with a few noninvasive adaptive works. For the initial cost, a parametric estimation has been carried out by starting from the cost of restoration of a historic building and adding the cost of the furniture, finishing, and installation system related to the new constructions of a building hosting those functions [74,75]. The same source of information has been consulted in order to evaluate the construction periods of building's adaptation. For the last criterion of the on-site assessments (involvement of local associations), it has been considered if spaces for local associations are provided or not; as it possible to appreciate from Table 2, only within the "nursing home" are they not designed.

Within the off-site criteria, which are aimed at evaluating the possible impact of the adaptive reuse on the context, the catchment area measures the significance of the project and its attractiveness on the local (1), regional (2), and national (3) scale. The more attractive function is the university research center, since it can interest students from the whole country, while the others have an impact on the regional scale. It is also the only adaptive reuse that promotes the improvement of public mobility for the accessibility of the area and the one with the higher mixed new job opportunities, since it would involve a high number of job sectors, including professors, administrative staff, and different outsourcing services. Not all the Sustainable Development Goals (SDGs) are satisfied by any alternative under evaluation. Specifically, the nursing home is more focused on factors related to wellbeing 
and the sustainable use of natural resources (No 3, 6, 7, 9), the university research center promotes, moreover, the gender equity and good quality of education (No 4, 5, 7, 8, 9, 15), the food district considers responsible production and consumption by supporting the generation of sustainable cities and communities (No 2, 7, 8, 9, 11, 12), and the cultural center is the only one concerned with the relationship with the institutions (No 4, 10, 11, 16).

The last criterion (involvement of the community) considers the number of age groups that could be involved and attracted by the project. ISTAT (National Institute of Statistics), an Italian public research organization, recognizes three different age groups ( $<14$ years old, between 15 and 64 years old, and $>65$ years old). Both the food district and the cultural Center can satisfy the expectations and needs of the entire population.

\subsubsection{Neutral Scenario}

Once the performances of each alternative have been detected, the MCDA requires the standardization phase, in which all the criteria lose their unit of measurement in order to be normalized by considering an a-dimensional scale based on the formulas $(1,2)$ previously explained. By performing this phase, it is possible to proceed with the evaluation that consists of the criteria weight elicitation [76]. Within this preliminary analysis, it was decided to visualize a neutral scenario where all the components included in the framework had the same importance for the achievement of the final objective, namely the adaptive reuse of Castello Visconteo in Cusago. The WSM, the compensatory aggregation procedure selected, was applied to obtain the final rank, which combined standardized scores and weights (Figure 3).

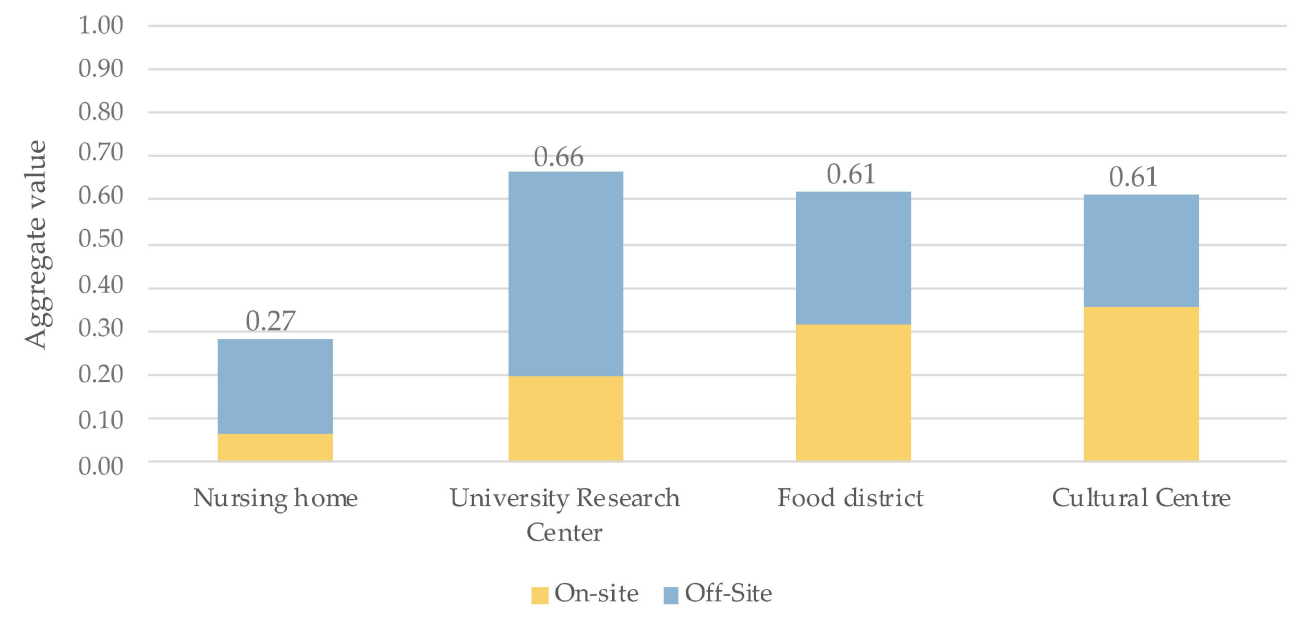

Figure 3. Rank of the neutral scenario.

Figure 3 presents the overall results and the contributions of the two macro-areas identified for the evaluation concerning the on-site and off-site aspects. By considering this neutral scenario, the most adaptive alternative among the ones defined is the university research center (0.66), followed in second place by the food district and the cultural center, which obtained the same evaluation (0.61), while in last place, and with a consistent detachment from the first three, there is the nursing home (0.27). Weights were not assigned, therefore this result is not surprising since the nursing home had the lower scores compared to the other alternatives for all the criteria considered, while the university research center, as an average, performed with higher scores. By taking into consideration the partial contribution, the alternative that would have a more positive impact on the building (on-site) is the cultural center (0.35), while the one that would more positively influence the context (off-site) is the university research center (0.47). In order to assess the validity of the results and check their consistency and robustness, it is necessary to perform a sensitivity analysis. 


\subsection{NAIADE Application}

According to the methodological approach proposed in Figure 1 and given the complexity of the problem and of the object under evaluation, which involves both tangible and intangible values, in order to make a more conscious decision about its future adaptive reuse, it is important to consider the opinion of actors involved in the process and experts with specific expertise and knowledge. For this purpose, the NAIADE method was applied for evaluating the social compromise solutions by eliciting the opinion of stakeholders identified as relevant for the decision problem about the four alternative scenarios.

As mentioned in Section 3, the NAIADE method involves the construction of an equity matrix that shows the opinions of the possible actors who may be involved in the redevelopment of the castle in Cusago with respect to each alternative. In this study, subjects with general interest were not considered, much less the local population. The subjects taken into consideration for the equity matrix were chosen after a careful analysis of the stakeholders and refer to the actors identified as most relevant for the building reuse process. Furthermore, some actors refer to the project alternatives hypothesized to make the evaluation as realistic as possible. All the group of expert has been defined with the letter $G$ followed by the number. The preliminary stakeholder analysis made it possible to identify the policymakers for the development of the project, such as the public administration (G1) and a cultural heritage expert (G2). Consultants from different sectors were involved to evaluate the alternatives from a technical point of view, including a food and beverage sector expert (G3), university expert (G4), and healthcare sector expert (G5). Furthermore, an economy expert (G6) was involved to validate the alternatives from an economic-financial feasibility point of view.

For this purpose, a questionnaire was prepared to interview the actors involved. The first part of the questionnaire presented the alternatives, evaluation criteria, and performance of each reuse solution for the building (Table 2). In the second part the interviewees were asked to evaluate the alternatives according to a 9-point semantic scale: perfect, very good, good, more or less good, moderate, more or less bad, bad, very bad, extremely bad. After assigning the score, each interviewee was asked to explain the rationale for the choice made for each alternative. The results of the different interviews are presented in Table 3.

Table 3. Equity matrix.

\begin{tabular}{ccccc}
\hline & \multicolumn{3}{c}{ Alternatives } \\
\cline { 2 - 5 } & Nursing Home & University Research Center & Food District & Cultural Center \\
\hline Public administration (G1) & Very Bad & Moderate & Good & Very Good \\
Cultural heritage expert (G2) & More or Less Bad & More or Less Good & Good & Good \\
Food and Beverage sector & Good & Good & Very Good & Very Good \\
expert (G3) & Bad & Very Good & Good & Moderate \\
University expert (G4) & Moderate & Good & More or Less Bad & Good \\
Healthcare sector expert (G5) & Bad & Good & Moderate & Perfect \\
Economy expert (G6) & & & &
\end{tabular}

According to the public administration (G1), the cultural center (very good) is one of the functions that the municipality wants, as there is no cultural center in Cusago. The food district (good) scenario turned out to be one of the preferred scenarios for G1, as the castle is in the agricultural park south of Cusago, where many local products companies do not have marketing places. The public actor proposed integration with other functions aimed at the local promotion of the territory. According to the public authority, a nursing home is not needed, much less the building is not suitable for this function.

The cultural heritage expert (G2) voted positively for the cultural center and university research center scenarios. According to the expert, the individual functions should be 
integrated with other outdoor activities. Both scenarios are combined with the vocation of the castle and respond to a real need.

The expert in the food and beverage sector (G3) considered all the project alternatives valid with a slight preference for the food district and the cultural Center. In his opinion, a food market gives space to local productions and events to enhance the food and wine heritage of the area and the possibility of diversifying the commercial offers and culinary attractiveness. In contrast, there may be low demand from the local population. The cultural scenario would make it possible to expand the groups that could benefit from the new spaces designed. The new spaces could also be used for local events already present in the municipality of Cusago. However, the scenario guarantees a low income, but a partnership with private individuals could support the financing of the work.

For the University expert (G4), a new research center would be a good opportunity given the complementarity with existing functions. Furthermore, the opening of a university in the municipality of Cusago could attract young people, representing an engine for local development. On the other hand, the "Nursery home" scenario is not compatible with the function of the building and with the context. Furthermore, the monofunctional destination would not allow local development of the area.

Most of the patients in nursing homes are elderly people, so perhaps them ending up in a place associated with its culture can have benefits according to the expert in the healthcare sector (G5). However, the function of the nursing home is complex and does not seem suitable for the asset being evaluated. Thanks to redevelopment as a university research center, the building would be enhanced by providing a structure open to the public. Furthermore, the possibility of combining educational activities with laboratory ones could be a plus for this destination. The creation of a food district may not enhance the asset given the short life cycle of the function. Creating a cultural center would create a reference point for the community and could be the meeting place of many cultures.

According to the economic expert (G6), a food district should be in a more central position in order to cover a greater user base and consequently obtain greater profits. In Cusago there is no cultural center and there are funding possibilities.

\section{Results}

\subsection{Conflicts and Coalitions between the Actors}

From the opinions elicited by the stakeholders and the equity matrix generated, the method allowed us to visualize a dendrogram, which is constructed considering pairs of actors and their similarity or conflict position against the alternatives defined (Figure 4).

The dendrogram presents the proximity and the distance of the stakeholders involved. The first coalition was realized by the public administration (G1) and the cultural heritage expert with very high proximity (0.73), since they shared the same idea about the adaptive reuse of the castle and promoted, moreover, its preservation by not changing drastically its designated use. Secondly, the previous coalition was joined by the economy expert (G6) with great credibility (0.71), since he already participated together with the public parties in some meetings aimed at discussing the future of the asset. Slightly lower, the third coalition, with again a good credibility (0.70), was built by the abovementioned stakeholders and the university expert (G4) and the healthcare sector expert. This could be related to their expectations about the promotion of the local economy through the exploitation of local knowledge and resources and they all agreed about the respect and preservation of the identity of the castle, which could be compromised by the selection of a too impactive function. The last joint coalition identified with medium proximity $(0.65)$ was shaped with the previous groups and the food and beverage sector expert. This is very interesting, since from the equity matrix he was the only one to judge the nursing home with a positive evaluation, thinking to the needs of the population and the economic return, but without paying attention to the compatibility of the function within a historic asset. 


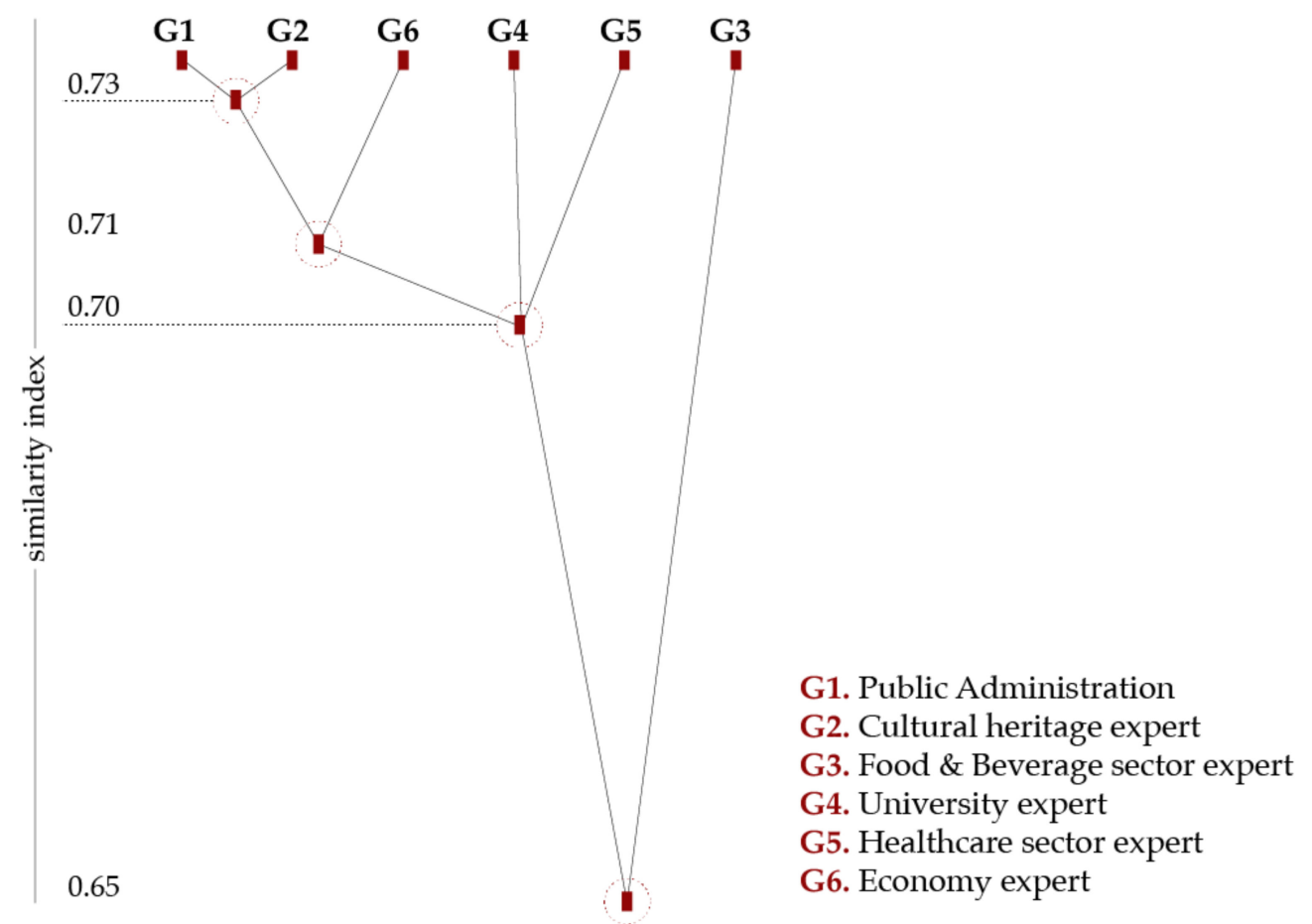

Figure 4. Dendrogram of coalition resulted from the equity matrix.

According to [28,77], to have an overall picture, it is important to better investigate the social compromise solution and the dendrogram to give validity and robustness to the results obtained. One of the most preferred alternatives is the cultural center, which was promoted by (G1) and (G6), and by (G2) and (G3), but they assessed it with the same scale as the food district, while for (G5) the university research center was present on the same level. Only (G4) did not judge in first or second place the cultural center, but rather in third, by assigning a higher evaluation to the university research center and the food district. The judgments were very similar with two exceptions, all the stakeholders agreed in evaluating the nursing home with a negative scale, while (G3) assigned it as(good) for the reasons previously explained, and the second refers to (G4), who evaluated the possibility of hosting a food district within the castle as (more or less bad).

By considering this further analysis, it is possible to conclude how to satisfy the group of stakeholders interviewed, who considered the most suitable adaptive reuse design to be a cultural center, with a possible combination and integration with other functions. It is clear moreover, the inconsistency between the neutral scenario and the opinion of the actors, which demonstrates the complexity of the problem and the necessity of consulting different stakeholders when both tangible and intangible values must be assessed.

\subsection{Sensitivity Analysis \\ Criteria Weights}

A sensitivity analysis was carried out for the validation of the results obtained from the multicriteria social analysis. To carry out this analysis, six new configurations of the WSM were created, based on the variation of the weights considering the opinion of the experts involved in the evaluation of the equity matrix. The questionnaire prepared for this study also included the evaluation of the criteria according to an order of importance. According to the SMARTER method, the interviewees were asked to order the evaluation criteria from the most important (1) to the least (10), remembering that each criterion can have a single level of importance different from the others; therefore, it is not possible to place more than one criterion on the same level of importance. Once the sort is obtained, SMARTER assigns the weights using the ROD method. According to the ROD method, each position corresponds to an assigned score; $1=0.2929,2=0.1929,3=0.1429,4=0.1096$, 
$5=0.0846,6=0.0646,7=0.0479,8=0.0336,9=0.021$, and $10=0.01$ [78]. This method is very convenient in decision-making as the ranking is identified more easily than the direct weights. The six configurations were compared with the average configuration of the experts. Figure 5 shows the results of the sensitivity analysis by putting together the different configurations. In detail, the outer circle shows the percentage of importance of each criterion, while the inner one indicates the percentage of importance according to the on-site or off-site dimension.
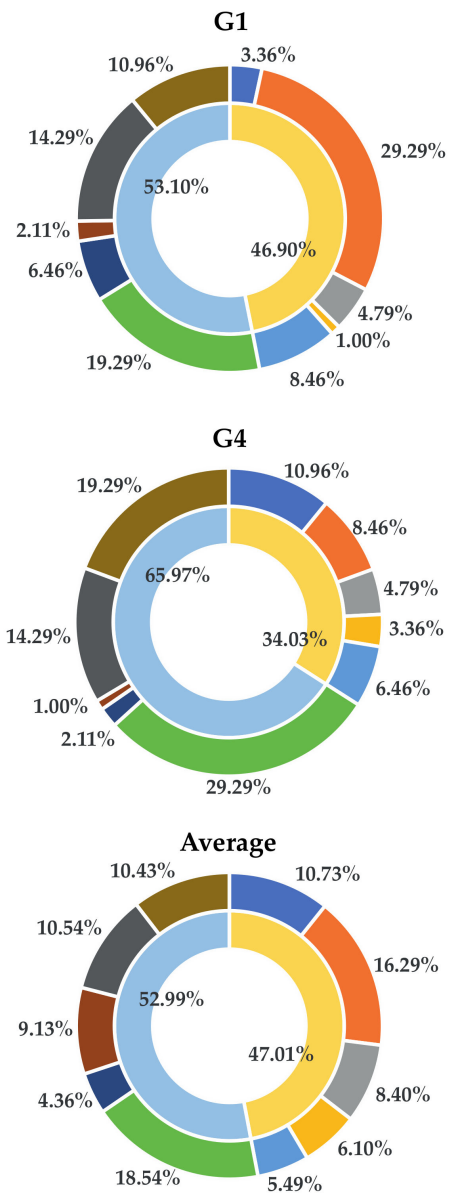

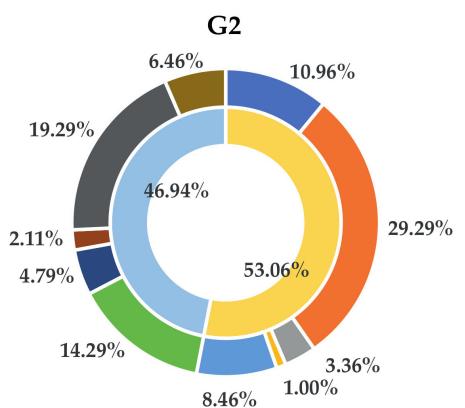

G5

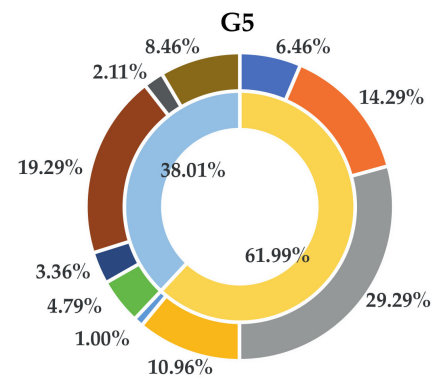

Evaluation criteria

- Design of public recreational spaces

- Initial cost

- Involvment of local associations

- Improvement of the accessibility

- Sustainable Development Goals (SDGs)

Criteria dimension

๓Off-site
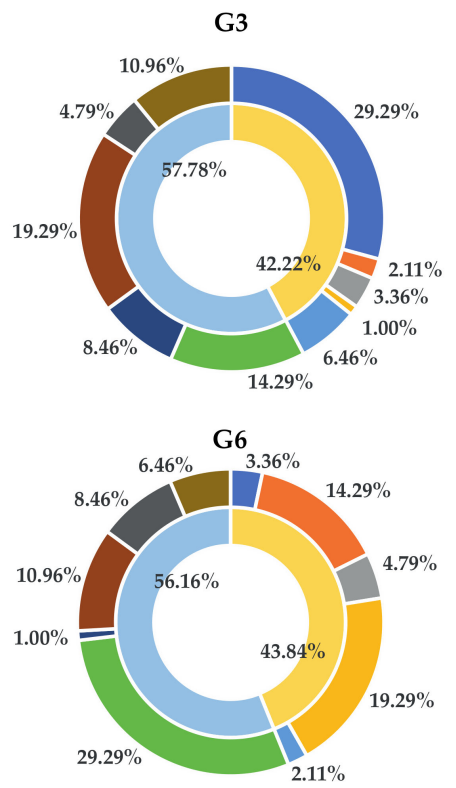

- Compatibility of the function with the property

- Construction periods of building's adaptation

- Social significance

- Mixed new job opportunities

- Involvement of the community

$\llbracket$ On-site

Figure 5. Criteria weights according to experts opinion (G1 = public administration; $G 2$ = cultural heritage expert; G3 = food and beverage expert; G4 = university expert; G5 = healthcare expert; G6 = economic expert).

The public administration expert (G1) considered the compatibility of the function with ownership as the most important criterion. The possibility of being able to extend the catchment area in a geographical sense followed. The sustainability of the scenario in line with the SDGs was the third most important criterion. From the overall ranking, it can be inferred that the G1 expert gave much more importance to off-site impacts (53.1\%), as expected, as his goal is to maximize the social benefit. The G2 expert, given his background being sensitive to cultural heritage, placed greater importance on on-site criteria. You value the compatibility of the function with the property as the most important. The fulfillment of the SDGs is an important criterion to be adopted in the adaptive reuse of the building. The food and beverage expert (G3) gave great importance to the criterion that maximizes the design of recreational public spaces. The criterion that promotes jobs, and therefore economic performance, was the second most important criterion. The university expert (G4) was the one who gave a lot of importance to the off-site dimension criteria that promotes local development, such as the catchment area and community involvement. On the contrary, the expert in the healthcare sector (G5) appeared to be the most attentive 
to the criteria concerning the site, giving importance to the initial investment costs, the compatibility of the new function with the building, and the shorter construction times. The economic expert (G6) gave a lot of importance to the catchment area, with the aim that the scenario can guarantee both a financial and socioeconomic return. The reduction of construction times and the compatibility of the project were, respectively, the second and third most important criteria in order to reduce the investment risks. From the average configuration of the weights provided by the experts (average graph), the importance share between on-site and off-site criteria was balanced. Maximizing the catchment area was the most important criterion (18.54\%). Given the historical value of the building, the criterion of compatibility of the function with the building obtained the second place of importance $(16.29 \%)$. The design of public recreational spaces $(10.73 \%)$, the fulfillment of the SDGs $(10.54 \%)$, and the involvement of the community $(10.43 \%)$ obtained the same level of importance. The least important criteria were the timing of completion $(6.10 \%)$, the involvement of local associations (5.49\%), and the improvement of accessibility (4.36\%).

Using the WSM method, it was possible to obtain a ranking of the alternatives based on the weights provided by the experts, and by the average, calculating the aggregate value of performances. As shown in Figure 6, the alternative nursing home was considered by all experts to be the worst. For G1, the university research center and cultural center were the best transformation scenarios for the reuse of the castle, in line with the preference expressed previously. Similarly, according to the weights provided, the cultural center was the most suitable solution for the expert G2, who supported a combination of different functions. University and food district seemed to be the most suitable solutions in accordance with the weights of the G3 expert. A lower preference was given to the cultural center reuse scenario. He believed that the scenario of the university research center was the most suitable for the reuse of the building. However, it is more difficult to undertake due to the long construction times of the connection infrastructures. For the university expert (G4), there was no strong distinction between reuse destinations. A slightly higher preference was given to the food district and the cultural center. She would have expected it due to the high level of local involvement of the functions. G5 was the actor that most reduced the gap between nursing home and the various other functions. The lower position of the food district in the ranking was justified by the fact that it may be less attractive over time. The university research center was the optimal solution for the economic expert (G6), in line with his expectations given the potentialities of the asset hosting large indoor spaces reserved for classrooms. The "average" scenario confirmed the results obtained previously, with a perfect congruence of all scenarios as the potential for transformation, except for the nursing home.

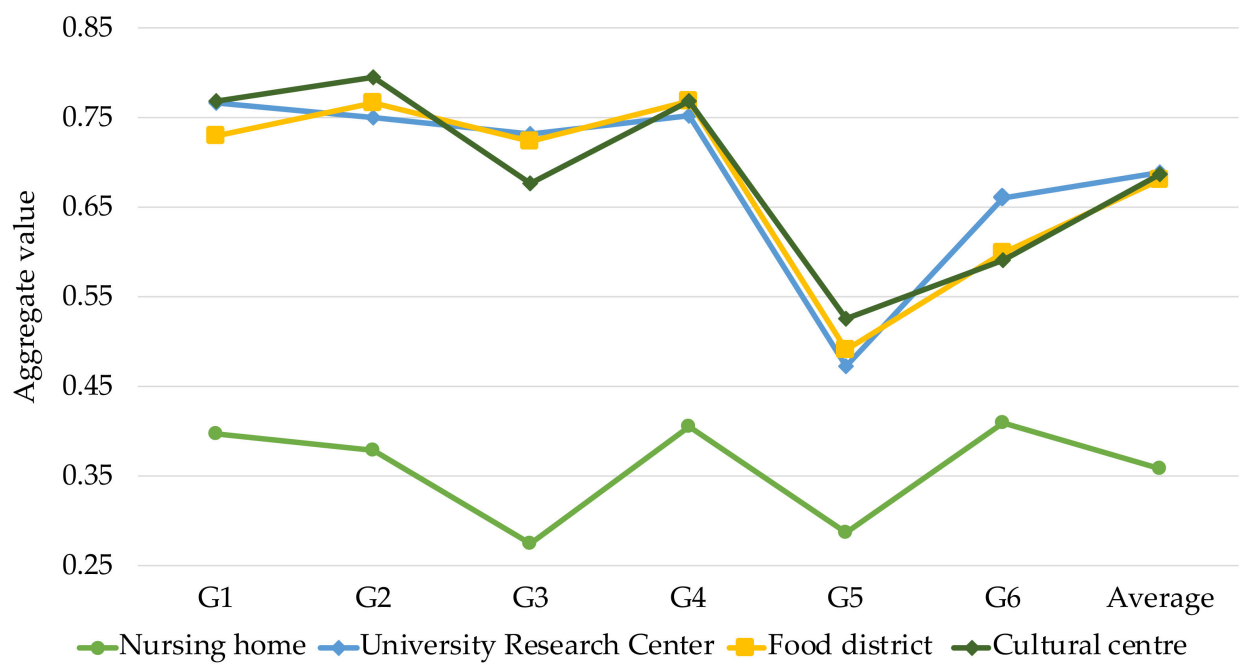

Figure 6. Scenarios ranking according to experts criteria weights $(\mathrm{G} 1=$ public administration; $\mathrm{G} 2$ = cultural heritage expert; G3 = food and beverage expert; G4 = university expert; G5 = healthcare expert; G6 = economic expert). 


\section{Discussion and Conclusions}

This study is part of a group of studies investigating the adaptive reuse of cultural buildings and shifting the focus from the idea of a cultural asset to be preserved to a vision of capital to be enhanced and reused. The contribution proposes the combination of different approaches aimed at investigating the most suitable adaptive reuse scenario for Castello Visconteo in Cusago. The new reuse scenarios aim to limit an exclusive use of these spaces for the benefit of a few individuals, and for a limited period. Furthermore, the COVID-19 pandemic period has led us to hypothesize functions that respond to the new needs that have arisen and to support the sectors most affected within a circular economy perspective. By the integration of the methodologies presented, it has been possible to visualize both technical and social results that could support the DM in making a more conscious decision. What emerged clearly by the analysis of the different results was a trend in which three alternatives, namely university research center, food district, and cultural center, ranked with very close evaluations, while nursing home was very distant from the others, both considering its performances and its social acceptability. In detail, the equity matrix was in line with the "What if" scenarios. It has been useful, moreover, to ask the stakeholders involved in the weights' elicitation and in the NAIADE phase to give an opinion about the rank obtained after their questionnaire. Most of them were satisfied and agreed about the results obtained, while the university expert (G4) and the economy expert (G6) were expecting another rank by considering their answers for the NAIADE by using the semantic scale. After all, they understood the incoherence that was given by the weights they assigned. It is important to underline again how the alternatives proposed are not propaedeutic to an in-depth analysis of the context and its needs, but the methodological approach, given the promotion of the interaction with stakeholders, the evaluation of both on-site and off-site aspects, and the definition of a set of criteria, which was based on the dimensions of the STEEP, could be strategic for the assessment of adaptive reuse scenario. It could be moreover applied when the building that has to be transformed is a cultural heritage site, whose preservation is recognized by the entire community as the holder of both tangible and intangible values. Moreover, this approach could also promote the generation of new and unexpected alternatives designed by the combination and integration of some of the functions previously defined in order to try to maximize the aspects involved in the analysis and define a more coherent tradeoff.

The paper aimed, moreover, to stress the importance of a decision support system when a complex decision has to be taken, in fact, as it has been well described by [52,79], a mono-criterion approach might neglect important aspects, while an approach that combines multidimensional and multi-stakeholder evaluations could be able to catch multiple perspectives and provide a more complete scenario.

As confirmed by the sensitivity analysis, it is possible to conclude that the NAIADE method is capable of capturing the preferences of stakeholders, allowing the inclusion of their opinions in the decision-making process. The NAIADE method lends itself well to the organization of focus groups aimed at acquiring information on the opinions of stakeholders with respect to the most varied scenarios of future development, allowing an easy comparison of opinions and the identification of possible alliances and conflicts. Being based on a 9-point qualitative scale, it is easily understood by the actors involved. In fact, the adoption of participatory approaches in spatial planning requires the use of appropriate tools that provide planners and public decision-makers with the ability to manage, as effectively and easily as possible, the knowledge gained in participatory planning processes. In addition, a model based on multicriteria analysis can lead to the evaluation phase of the decision-making process in the preliminary stages when information is not detailed. Among the limitations of the method, it must be emphasized that the evaluations are characterized by subjectivity in terms of priorities and preferences that condition the results. The subjective effect can be checked by comparing the results of the NAIADE method with a multicriteria evaluation model that attributes the same weight, therefore the same priority, to the different criteria. Moreover, the use of a compensatory 
aggregation procedure, such as the WSM, has positive effects in terms of results, since the ranking defines the most suitable alternative, i.e., the one able to find a tradeoff among the dimensions involved. At the same time, criticalities could be detected. In fact, in some cases, thresholds and levels of acceptability have to be established, since the respect of specific requirements is mandatory, especially when the object of the evaluation is a cultural heritage site. The support of a partially compensatory method could be strategic in order to take into consideration possible constraints.

According to this first experience, it is possible to underline the uniqueness of the case study, which carried peculiar characteristics and had a specific significance for the community and the place where it is located. Even if the approach has been tested only once, what could be replicated is the methodological approach, based on the integration of different methodologies, which implements an overall understanding and analysis of the problem and is based on the interaction with multidisciplinary actors aimed at catching the multi-perspectives of the problem. On the contrary some, phases are case-based, i.e., related to the problem under investigation and its contexts, such as the set of criteria, which in this case were based on a literature review but were selected in accordance with the castle specifically. This aspect could be described as a limit, but at the same time, it strengthens and validates the selection of a consistent evaluation framework. Therefore, the proposed model can be used on other adaptive reuse projects in order to test its validity, paying attention to the phases that require a more detailed and case-based analysis.

To conclude, as future perspectives, additional stakeholders can be involved to compare the alternatives proposed for the case study investigated in this work in order to improve the interaction phase by expanding the categories of actors interviewed and at the same time values elicited.

Author Contributions: Conceptualization, F.D. and M.D.; methodology, F.D. and M.D.; software, F.D. and M.D.; validation, F.D., M.D., R.S. and L.S.; formal analysis, F.D. and M.D.; investigation, F.D., M.D., R.S. and L.S.; resources, F.D., M.D., R.S. and L.S.; data curation, F.D. and M.D.; writingoriginal draft preparation, F.D. and M.D; writing-review and editing, F.D., M.D., R.S. and L.S.; visualization, F.D. and M.D.; supervision, L.S. All authors have read and agreed to the published version of the manuscript.

Funding: This research received no external funding.

Institutional Review Board Statement: Not applicable.

Informed Consent Statement: Not applicable.

Data Availability Statement: Not applicable.

Conflicts of Interest: The authors declare no conflict of interest.

Appendix A. Literature Review

\begin{tabular}{|c|c|c|c|}
\hline Author & Aim & Criteria & Sub-Criteria \\
\hline \multirow{9}{*}{ Yau (2009) [34] } & \multirow{9}{*}{$\begin{array}{l}\text { to present an MCDM model } \\
\text { on the criteria for decision } \\
\text { making, which can have many } \\
\text { applications in heritage } \\
\text { conservation decision making }\end{array}$} & \multirow{3}{*}{ Land use } & Compatibility \\
\hline & & & Congruity \\
\hline & & & Historical integrity \\
\hline & & \multirow{3}{*}{ Design and landscape } & Visual quality \\
\hline & & & Development scale \\
\hline & & & Barrier-free access \\
\hline & & \multirow{3}{*}{ Infrastructural impacts } & Transport system \\
\hline & & & $\begin{array}{l}\text { Plumbing and } \\
\text { drainage }\end{array}$ \\
\hline & & & Electricity and gas \\
\hline
\end{tabular}




\begin{tabular}{|c|c|c|c|}
\hline Author & Aim & Criteria & Sub-Criteria \\
\hline \multirow{9}{*}{ Yau (2009) [34] } & \multirow{9}{*}{$\begin{array}{l}\text { to present an MCDM model } \\
\text { on the criteria for decision } \\
\text { making, which can have many } \\
\text { applications in heritage } \\
\text { conservation decision making }\end{array}$} & \multirow{3}{*}{ Environmental impacts } & Tree protection \\
\hline & & & Pollutions \\
\hline & & & Nuisances \\
\hline & & \multirow{3}{*}{ Engineering concerns } & Structural conditions \\
\hline & & & Maintenance viability \\
\hline & & & Geotechnical concerns \\
\hline & & \multirow{3}{*}{ Financial performance } & Initial costs \\
\hline & & & Recurrent costs \\
\hline & & & Economic benefits \\
\hline \multirow{8}{*}{$\begin{array}{l}\text { Turskis et al. } \\
\text { (2013) [43] }\end{array}$} & \multirow{8}{*}{$\begin{array}{l}\text { multiple criteria assessment of } \\
\text { alternatives of the cultural } \\
\text { heritage renovation projects in } \\
\text { Vilnius city. }\end{array}$} & Historical, cultural, and memorial & \\
\hline & & Remains of different eras of construction & \\
\hline & & Stylistic epochs remain inside & \\
\hline & & $\begin{array}{l}\text { Stylistic epoch's remains of } \\
\text { the building facades }\end{array}$ & \\
\hline & & Architectural—composite value of facades & \\
\hline & & Building functionality in old town area & \\
\hline & & Building's construction technology and quality & \\
\hline & & Construction periods of building's evolution & \\
\hline \multirow{5}{*}{$\begin{array}{l}\text { Ferretti et al. } \\
\text { (2014) [45] }\end{array}$} & \multirow{5}{*}{$\begin{array}{c}\text { sustainability assessment in } \\
\text { cultural heritage projects } \\
\text { using the Multi-Attribute } \\
\text { Value Theory (MAVT) } \\
\text { approach }\end{array}$} & Quality of the context & \\
\hline & & Economic activities & \\
\hline & & Flexibility of the building & \\
\hline & & Accessibility & \\
\hline & & Conservation level & \\
\hline \multirow{8}{*}{$\begin{array}{l}\text { Oppio \& Bottero } \\
\text { (2017) [33] }\end{array}$} & \multirow{8}{*}{$\begin{array}{l}\text { the use of a multi } \\
\text { methodological approach } \\
\text { based on choice experiments } \\
\text { and social multicriteria } \\
\text { evaluation to support the } \\
\text { adaptive reuse }\end{array}$} & Flexibility & \\
\hline & & Promotion & \\
\hline & & Accessibility & \\
\hline & & Public spaces & \\
\hline & & Cost & \\
\hline & & Events & \\
\hline & & Invasiveness & \\
\hline & & Target & \\
\hline
\end{tabular}




\begin{tabular}{|c|c|c|c|}
\hline Author & Aim & Criteria & Sub-Criteria \\
\hline \multirow{13}{*}{$\begin{array}{c}\text { Della Spina } \\
\text { (2019) [44] }\end{array}$} & \multirow{13}{*}{$\begin{array}{l}\text { integrated evaluation model } \\
\text { based on the combined use of } \\
\text { multi-criteria techniques, } \\
\text { which helps to classify } \\
\text { adaptive reuse strategies of } \\
\text { unused cultural heritage } \\
\text { assets and supports } \\
\text { decision-makers in the } \\
\text { implementation of } \\
\text { development strategies in } \\
\text { vulnerable contexts }\end{array}$} & \multirow{4}{*}{ Economic } & Attractiveness \\
\hline & & & Permanent jobs \\
\hline & & & Investment costs \\
\hline & & & Payback period (PBP) \\
\hline & & \multirow{3}{*}{ Social and Culture } & $\begin{array}{l}\text { Sociocultural } \\
\text { associations }\end{array}$ \\
\hline & & & $\begin{array}{l}\text { Cultural and } \\
\text { recreational services }\end{array}$ \\
\hline & & & $\begin{array}{c}\text { Potential for cultural } \\
\text { initiatives }\end{array}$ \\
\hline & & \multirow{6}{*}{ Urban landscape quality } & Pedestrian connections \\
\hline & & & $\begin{array}{l}\text { Proximity to public } \\
\text { transport }\end{array}$ \\
\hline & & & Permeable surface area \\
\hline & & & Traffic restriction \\
\hline & & & Quality of landscape \\
\hline & & & Mixed Functionality \\
\hline \multirow{10}{*}{$\begin{array}{l}\text { Haroun et al. } \\
(2019)[38]\end{array}$} & \multirow{10}{*}{$\begin{array}{l}\text { to introduce an appropriate } \\
\text { evaluation tool to support the } \\
\text { efficiency in selecting the } \\
\text { optimum solution for } \\
\text { adaptive reuse of heritage } \\
\text { buildings }\end{array}$} & Heritage value & $\begin{array}{c}\text { Protection and } \\
\text { enhancement heritage } \\
\text { significant }\end{array}$ \\
\hline & & \multirow{4}{*}{ Architectural value } & Compatibility \\
\hline & & & $\begin{array}{l}\text { Recognizability of } \\
\text { heritage and new } \\
\text { function }\end{array}$ \\
\hline & & & $\begin{array}{l}\text { The respectability of } \\
\text { building's system }\end{array}$ \\
\hline & & & $\begin{array}{l}\text { Building's physical } \\
\text { stability }\end{array}$ \\
\hline & & \multirow{2}{*}{ Economic performance } & Economic benefits \\
\hline & & & Adaptation costs \\
\hline & & Social value & Effect on society \\
\hline & & \multirow[t]{2}{*}{ Environmental impact } & $\begin{array}{l}\text { Congruity with } \\
\text { land uses }\end{array}$ \\
\hline & & & Accessibility \\
\hline \multirow{5}{*}{$\begin{array}{l}\text { Nesticò \& Somma } \\
\text { (2019) [39] }\end{array}$} & \multirow{5}{*}{$\begin{array}{l}\text { to identify an effective } \\
\text { approach to establish the best } \\
\text { use of a historic building }\end{array}$} & Social & $\begin{array}{l}\text { Community } \\
\text { involvement }\end{array}$ \\
\hline & & & New workers \\
\hline & & Cultural & Cultural effects \\
\hline & & & $\begin{array}{l}\text { Historical- } \\
\text { architectural } \\
\text { compatibility }\end{array}$ \\
\hline & & Financial & $\begin{array}{c}\text { Return On Investment } \\
\text { (ROI) }\end{array}$ \\
\hline
\end{tabular}




\begin{tabular}{|c|c|c|c|}
\hline Author & Aim & Criteria & Sub-Criteria \\
\hline \multirow{21}{*}{$\begin{array}{l}\text { Pavlovskis et al. } \\
\text { (2019) [40] }\end{array}$} & \multirow{21}{*}{$\begin{array}{l}\text { application of the multiple } \\
\text { criteria decision-making } \\
\text { (MCDM) method under } \\
\text { uncertainty, namely the rough } \\
\text { weighted aggregated sum } \\
\text { product assessment } \\
\text { (WASPAS), for ranking } \\
\text { alternatives according to } \\
\text { multiple criteria. }\end{array}$} & \multirow{4}{*}{ Economic benefit/expenses of changes } & $\begin{array}{l}\text { Investment to investigation } \\
\text { and research }\end{array}$ \\
\hline & & & Investment in design; \\
\hline & & & $\begin{array}{l}\text { Investment in } \\
\text { reconstruction works }\end{array}$ \\
\hline & & & $\begin{array}{l}\text { Generating income for the } \\
\text { municipality/city }\end{array}$ \\
\hline & & \multirow{4}{*}{ Influence on social environment } & $\begin{array}{c}\text { Job creation for } \\
\text { municipal/city residents }\end{array}$ \\
\hline & & & $\begin{array}{l}\text { Benefits for city/country } \\
\text { society }\end{array}$ \\
\hline & & & Benefits for private business \\
\hline & & & $\begin{array}{c}\text { Benefits for heritage } \\
\text { preservation }\end{array}$ \\
\hline & & \multirow{4}{*}{ Impact on natural environment } & $\begin{array}{l}\text { Preserving the surrounding } \\
\text { landscape }\end{array}$ \\
\hline & & & $\begin{array}{l}\text { Possibilities of park use for } \\
\text { public needs and recreation }\end{array}$ \\
\hline & & & $\begin{array}{l}\text { Pollution during } \\
\text { reconstruction works }\end{array}$ \\
\hline & & & $\begin{array}{l}\text { Pollution during operation of } \\
\text { the facility }\end{array}$ \\
\hline & & \multirow{5}{*}{ Historical—cultural value preservation } & $\begin{array}{l}\text { Preserving the building's } \\
\text { authenticity }\end{array}$ \\
\hline & & & $\begin{array}{l}\text { Activities that help propagate } \\
\text { history, culture }\end{array}$ \\
\hline & & & $\begin{array}{l}\text { Public access to heritage } \\
\text { and history }\end{array}$ \\
\hline & & & $\begin{array}{l}\text { Technical-economic value of } \\
\text { an object }\end{array}$ \\
\hline & & & $\begin{array}{c}\text { Architectural-compositional } \\
\text { value of an object }\end{array}$ \\
\hline & & \multirow{4}{*}{$\begin{array}{c}\text { Technological-architectural } \\
\text { possibilities }\end{array}$} & $\begin{array}{c}\text { Volume of } \\
\text { reconstruction works }\end{array}$ \\
\hline & & & $\begin{array}{l}\text { Suitability of the internal } \\
\text { layout for the purpose of } \\
\text { conversion }\end{array}$ \\
\hline & & & $\begin{array}{l}\text { Infrastructure adaptation } \\
\text { possibilities }\end{array}$ \\
\hline & & & $\begin{array}{l}\text { Lifetime of the building after } \\
\text { reconstruction }\end{array}$ \\
\hline
\end{tabular}




\begin{tabular}{|c|c|c|c|}
\hline Author & Aim & Criteria & Sub-Criteria \\
\hline \multirow{6}{*}{$\begin{array}{l}\text { Stević et al. } \\
\text { (2019) [41] }\end{array}$} & \multirow{6}{*}{$\begin{array}{l}\text { to evaluate the attractiveness } \\
\text { of some of the main cultural } \\
\text { sites/tourism attractions in } \\
\text { Porto, Portugal }\end{array}$} & Historic value & \\
\hline & & Aesthetic/artistic value & \\
\hline & & Representativeness & \\
\hline & & State of preservation & \\
\hline & & Infrastructure and accessibility & \\
\hline & & Social significance & \\
\hline \multirow{4}{*}{$\begin{array}{l}\text { Abastante et al. } \\
\text { (2020) [27] }\end{array}$} & \multirow{4}{*}{$\begin{array}{l}\text { combination of different } \\
\text { analyses on the territory and a } \\
\text { multicriteria decision analysis } \\
\text { (MCDA) to pick out crucial } \\
\text { decisions related to the final } \\
\text { destination of some spaces } \\
\text { involving the community. }\end{array}$} & Tourism & \\
\hline & & Didactic/Recreational & \\
\hline & & Sport & \\
\hline & & Socio/cultural & \\
\hline
\end{tabular}

Presence of historical-cultural places within $1 \mathrm{~km}$

\begin{tabular}{|c|c|c|c|}
\hline & & & places within $1 \mathrm{~km}$ \\
\hline & & & $\begin{array}{l}\text { Quality of the urban } \\
\text { landscape }\end{array}$ \\
\hline & $\begin{array}{l}\text { a multicriteria analysis to } \\
\text { decision support, starting }\end{array}$ & Urban sustainability & $\begin{array}{l}\text { Accessibility by } \\
\text { private car }\end{array}$ \\
\hline Della Snina (2020) [9] & $\begin{array}{c}\text { with a multistakeholder } \\
\text { decision analysis (M-SDA), in } \\
\text { order to assist }\end{array}$ & & $\begin{array}{c}\text { Presence of } \\
\text { commercial } \\
\text { activities nearby }\end{array}$ \\
\hline Salerno (2020) [13] & $\begin{array}{l}\text { suitable scenarios to trigger } \\
\text { circular development } \\
\text { processes, taking into account }\end{array}$ & & $\begin{array}{c}\text { Presence of } \\
\text { accommodation and } \\
\text { hospitality services }\end{array}$ \\
\hline & $\begin{array}{l}\text { the role of cultural heritage in } \\
\text { a systemic landscape }\end{array}$ & & $\begin{array}{l}\text { Total property } \\
\text { availability }\end{array}$ \\
\hline & & Project sustainability & $\begin{array}{c}\text { Flexibility of spaces to } \\
\text { new functions }\end{array}$ \\
\hline & & & Degradation level \\
\hline & & & Investment costs \\
\hline & & Economic sustainability & Payback period \\
\hline & & & $\begin{array}{l}\text { Financial appeal for } \\
\text { private investors }\end{array}$ \\
\hline
\end{tabular}




\begin{tabular}{|c|c|c|c|}
\hline Author & Aim & Criteria & Sub-Criteria \\
\hline \multirow{10}{*}{$\begin{array}{l}\text { Ribera et al. } \\
\text { (2020) [17] }\end{array}$} & \multirow{10}{*}{$\begin{array}{l}\text { to define an economic } \\
\text { evaluation model useful for } \\
\text { the public decision-maker in } \\
\text { choosing the new uses for the } \\
\text { historic buildings, compatible } \\
\text { with the historical tradition }\end{array}$} & Social & \\
\hline & & Cultural & \\
\hline & & Financial & \\
\hline & & Involvement of the community & \\
\hline & & Level of the employment & \\
\hline & & Cultural repercussions on the community & \\
\hline & & $\begin{array}{l}\text { Compatibility of the function with the } \\
\text { historical-architectural characteristics of } \\
\text { the property }\end{array}$ & \\
\hline & & Representativeness of the function & \\
\hline & & Housing impact & \\
\hline & & $\begin{array}{l}\text { Respect of the criterion of minimum } \\
\text { intervention }\end{array}$ & \\
\hline \multirow{12}{*}{$\begin{array}{l}\text { Della Spina } \\
(2021) \text { [42] }\end{array}$} & \multirow{12}{*}{$\begin{array}{l}\text { experimenting an innovative } \\
\text { approach to the design and } \\
\text { evaluation of complex } \\
\text { processes concerning the } \\
\text { rehabilitation of the } \\
\text { abandoned railway cultural } \\
\text { heritage }\end{array}$} & \multirow{3}{*}{ Strengths } & $\begin{array}{l}\text { Cultural historical } \\
\text { value }\end{array}$ \\
\hline & & & $\begin{array}{l}\text { Current state of } \\
\text { conservation }\end{array}$ \\
\hline & & & $\begin{array}{l}\text { Level of accessibility } \\
\text { to asset }\end{array}$ \\
\hline & & \multirow{3}{*}{ Weaknesses } & $\begin{array}{l}\text { Current destination } \\
\text { and use }\end{array}$ \\
\hline & & & Current property \\
\hline & & & $\begin{array}{l}\text { Operating and } \\
\text { maintenance costs }\end{array}$ \\
\hline & & \multirow{3}{*}{ Opportunities } & $\begin{array}{c}\text { Landscape quality of } \\
\text { the context }\end{array}$ \\
\hline & & & $\begin{array}{l}\text { Flexibility and } \\
\text { transformative } \\
\text { potential }\end{array}$ \\
\hline & & & $\begin{array}{l}\text { Connection to public } \\
\text { infrastruc- } \\
\text { tures/services }\end{array}$ \\
\hline & & \multirow{3}{*}{ Threats } & $\begin{array}{l}\text { Regulatory risks in the } \\
\text { use of the property }\end{array}$ \\
\hline & & & $\begin{array}{l}\text { Lack of funding and } \\
\text { potential investors }\end{array}$ \\
\hline & & & $\begin{array}{l}\text { Degradation of the } \\
\text { built environment }\end{array}$ \\
\hline
\end{tabular}

\section{References}

1. Cerreta, M.; Elefante, A.; La Rocca, L. A creative living lab for the adaptive reuse of the morticelli church: The ssmoll project. Sustainability 2020, 12, 561. [CrossRef]

2. Bottero, M.C.; Dell'Anna, F.; Gobbo, G.L. A PROMETHEE-Based Approach for Designing the Reuse of an Abandoned Railway in the Monferrato Region, Italy. Int. J. Multicriteria Decis. Mak. 2019, 8, 60-83. [CrossRef]

3. Cerreta, M.; Daldanise, G. Community branding (Co-bra): A collaborative decision making process for urban regeneration. In Lecture Notes in Computer Science (Including Subseries Lecture Notes in Artificial Intelligence and Lecture Notes in Bioinformatics), Proceedings of the International Conference on Computational Science and Its Applications, Trieste, Italy, 3-6 July 2017; Springer: Cham, Switzerland, 2017; pp. 730-746. [CrossRef] 
4. Bottero, M.; Caprioli, C.; Berta, M. Urban Problems and Patterns of Change: The Analysis of a Downgraded Industrial Area in Turin. In Values and Functions for Future Cities; Springer: Cham, Switzerland, 2020; pp. 385-401.

5. Yoon, J.; Lee, J. Adaptive reuse of apartments as heritage assets in the Seoul station urban regeneration area. Sustainability 2019, 11, 3124. [CrossRef]

6. Torrieri, F.; Fumo, M.; Sarnataro, M.; Ausiello, G. An integrated decision support system for the sustainable reuse of the former monastery of "ritiro del carmine" in campania region. Sustainability 2019, 11, 5244. [CrossRef]

7. Bottero, M.; D'Alpaos, C.; Oppio, A. Ranking of adaptive reuse strategies for abandoned industrial heritage in vulnerable contexts: A multiple criteria decision aiding approach. Sustainability 2019, 11, 785. [CrossRef]

8. De Medici, S.; De Toro, P.; Nocca, F. Cultural heritage and sustainable development: Impact assessment of two adaptive reuse projects in Siracusa, Sicily. Sustainability 2020, 12, 311. [CrossRef]

9. Della Spina, L. Adaptive sustainable reuse for cultural heritage: A multiple criteria decision aiding approach supporting urban development processes. Sustainability 2020, 12, 1363. [CrossRef]

10. Stival, C.A.; Berto, R.; Morano, P.; Rosato, P. Reuse of Vernacular Architecture in Minor Alpine Settlements: A Multi-Attribute Model for Sustainability Appraisal. Sustainability 2020, 12, 6562. [CrossRef]

11. Oppio, A.; Bottero, M.; Ferretti, V. Designing Adaptive Reuse Strategies for Cultural Heritage with Choice Experiments. In Appraisal: From Theory to Practice; Springer: Cham, Switzerland, 2017; pp. 303-315.

12. Department of the Environment and Heritage. Adaptive Reuse: Preserving our Past, Building our Future; Department of the Environment and Heritage: Camberra, Australia, 2004.

13. Salerno, E. Identifying value-increasing actions for cultural heritage assets through sensitivity analysis of multicriteria evaluation results. Sustainability 2020, 12, 9238. [CrossRef]

14. Vehbi, B.O.; Günçe, K.; Iranmanesh, A. Multi-Criteria Assessment for Defining Compatible New Use: Old Administrative Hospital, Kyrenia, Cyprus. Sustainability 2021, 13, 1922. [CrossRef]

15. Tu, H.-M. Sustainable Heritage Management: Exploring Dimensions of Pull and Push Factors. Sustainability 2020, $12,8219$. [CrossRef]

16. Aigwi, I.E.; Egbelakin, T.; Ingham, J.; Phipps, R.; Rotimi, J.; Filippova, O. A performance-based framework to prioritise underutilised historical buildings for adaptive reuse interventions in New Zealand. Sustain. Cities Soc. 2019, 48. [CrossRef]

17. Ribera, F.; Nesticò, A.; Cucco, P.; Maselli, G. A multicriteria approach to identify the Highest and Best Use for historical buildings. J. Cult. Herit. 2020, 41, 166-177. [CrossRef]

18. Daldanise, G. From place-branding to community-branding: A collaborative decision-making process for cultural heritage enhancement. Sustainability 2020, 12, 399. [CrossRef]

19. United Nations. The Millennium Development Goals Report 2015; Millennium Development Goals Report; UN: New York, NY, USA, 2016; ISBN 9789210574662.

20. De Gregorio, S.; De Vita, M.; De Berardinis, P.; Palmero, L.; Risdonne, A. Designing the sustainable adaptive reuse of industrial heritage to enhance the local context. Sustainability 2020, 12, 9059. [CrossRef]

21. Foster, G.; Kreinin, H.; Stagl, S. The future of circular environmental impact indicators for cultural heritage buildings in Europe. Environ. Sci. Eur. 2020, 32. [CrossRef]

22. Dell'Ovo, M.; Bassani, S.; Stefanina, G.; Oppio, A. Memories at risk. How to support decisions about abandoned industrial heritage regeneration. Valori e Valutazioni 2020, 2020, 107-115.

23. Assumma, V.; Bottero, M.; Monaco, R. Landscape Economic Attractiveness: An Integrated Methodology for Exploring the Rural Landscapes in Piedmont (Italy). Land 2019, 8, 105. [CrossRef]

24. Mangialardo, A.; Micelli, E. Reconstruction or Reuse? How Real Estate Values and Planning Choices Impact Urban Redevelopment. Sustainability 2020, 12, 4060. [CrossRef]

25. Fabbri, R.; Gabrielli, L.; Ruggeri, A.G. Interactions between restoration and financial analysis: The case of Cuneo War Wounded House. J. Cult. Herit. Manag. Sustain. Dev. 2018, 8, 145-161. [CrossRef]

26. Bottero, M.; Dell'Anna, F.; Nappo, M. Evaluating Tangible and Intangible Aspects of Cultural Heritage: An Application of the PROMETHEE Method for the Reuse Project of the Ceva-Ormea Railway. In Integrated Evaluation for the Management of Contemporary Cities; Mondini, G., Fattinnanzi, E., Oppio, A., Bottero, M., Stanghellini, S., Eds.; Springer: Cham, Switzerland, 2018; pp. 285-295.

27. Abastante, F.; Lami, I.M.; Mecca, B. How to revitalise a historic district: A stakeholders-oriented assessment framework of adaptive reuse. Green Energy Technol. 2020, 3-20. [CrossRef]

28. Bottero, M.; Datola, G. Addressing social sustainability in urban regeneration processes. An application of the social multi-criteria evaluation. Sustainability 2020, 12, 7579.

29. Napoli, G.; Leone, M. The urban park as a "social island". the ANP in the participatory project of Parco Uditore in Palermo. In Green Energy and Technology; Springer: Berlin, Germany, 2020; pp. 229-248.

30. Giuliani, F.; De Falco, A.; Santini, L. A Stakeholder Analysis for the Adaptive Reuse Assessment of Architectural Heritage: Towards an Integrated Approach; Springer: Cham, Switzerland, 2020; pp. 311-333.

31. Munda, G. Multicriteria Evaluation in a Fuzzy Environment: The Naiade Method. In Multicriteria Evaluation in a Fuzzy Environment. Contributions to Economics; Physica-Verlag HD: Berlin, Germany, 1995; pp. 131-148.

32. Munda, G. A NAIADE based approach for sustainability benchmarking. Int. J. Environ. Technol. Manag. 2006, 6, 65. [CrossRef] 
33. Oppio, A.; Bottero, M. Conflicting values in designing adaptive reuse for cultural heritage. A case study of social multicriteria evaluation. Lecture Notes in Computer Science (Including Subseries Lecture Notes in Artificial Intelligence and Lecture Notes in Bioinformatics), Proceedings of the International Conference on Computational Science and Its Applications, Trieste, Italy, 3-6 July 2017; Springer: Cham, Switzerland, 2017; pp. 607-623.

34. Nadkarni, R.R.; Puthuvayi, B. A comprehensive literature review of Multi-Criteria Decision Making methods in heritage buildings J. Build. Eng. 2020, 32, 101814. [CrossRef]

35. Bottero, M.; Bragaglia, F.; Caruso, N.; Datola, G.; Dell'Anna, F. Experimenting community impact evaluation (CIE) for assessing urban regeneration programmes: The case study of the area 22@ Barcelona. Cities 2020, 99, 102464. [CrossRef]

36. Capolongo, S.; Sdino, L.; Dell'Ovo, M.; Moioli, R.; Della Torre, S. How to assess urban regeneration proposals by considering conflicting values. Sustainability 2019, 11, 3877. [CrossRef]

37. Yau, Y. Multi-criteria decision making for urban built heritage conservation: Application of the analytic hierarchy process. J. Build. Apprais. 2009, 4, 191-205. [CrossRef]

38. Haroun, H.A.A.F.; Bakr, A.F.; Hasan, A.E.S. Multi-criteria decision making for adaptive reuse of heritage buildings: Aziza Fahmy Palace, Alexandria, Egypt. Alex. Eng. J. 2019, 58, 467-478. [CrossRef]

39. Nesticò, A.; Somma, P. Comparative analysis of multi-criteria methods for the enhancement of historical buildings. Sustainability 2019, 11, 4526. [CrossRef]

40. Pavlovskis, M.; Migilinskas, D.; Antucheviciene, J.; Kutut, V. Ranking of heritage building conversion alternatives by applying BIM and MCDM: A case of Sapieha Palace in Vilnius. Symmetry 2019, 11, 973. [CrossRef]

41. Stević, I.; Stević, S.R.; de Jesus Breda, Z.M. Application of MCDM methods to tourism evaluation of cultural sites. In Cultural Urban Heritage; Springer: Cham, Switzerland, 2019; pp. 357-381. [CrossRef]

42. Della Spina, L. Strategic planning and decision making: A case study for the integrated management of cultural heritage assets in southern italy. Smart Innov. Syst. Technol. 2021, 178 SIST, 1116-1130. [CrossRef]

43. Turskis, Z.; Zavadskas, E.K.; Kutut, V. A model based on ARAS-G and AHP methods for multiple criteria prioritizing of heritage value. Int. J. Inf. Technol. Decis. Mak. 2013, 12, 45-73. [CrossRef]

44. Della Spina, L. Multidimensional assessment for "culture-led" and "community-driven" urban regeneration as driver for trigger economic vitality in urban historic centers. Sustainability 2019, 11, 7237. [CrossRef]

45. Ferretti, V.; Bottero, M.; Mondini, G. Decision making and cultural heritage: An application of the Multi-Attribute Value Theory for the reuse of historical buildings. J. Cult. Herit. 2014, 15, 644-655. [CrossRef]

46. Simon, H.A. Information Processing Models of Cognition. Annu. Rev. Psychol. 1979, 30, 363-396. [CrossRef] [PubMed]

47. Korhonen, J.; Honkasalo, A.; Seppälä, J. Circular Economy: The Concept and its Limitations. Ecol. Econ. 2018, 143, 37-46. [CrossRef]

48. Cadrien; Messaadia, M.; Majumdar, A.; Eynard, B. STEEP analysis as a tool for building technology roadmaps. In Proceedings of the Internationale Challenges e-2011 Conference, Florence, Italy, 26-28 October 2011; pp. 26-28.

49. Teo, E.A.L.; Lin, G. Determination of strategic adaptation actions for public housing in Singapore. Build. Environ. 2011, 46, 1480-1488. [CrossRef]

50. Dell'Anna, F. Green jobs and energy efficiency as strategies for economic growth and the reduction of environmental impacts. Energy Policy 2020, 112031. [CrossRef]

51. Roy, B. Decision-aid and decision-making. Eur. J. Oper. Res. 1990, 45, 324-331. [CrossRef]

52. Roy, B. Paradigms and challenges. In International Series in Operations Research and Management Science; Springer: New York, NY, USA, 2005; Volume 78, pp. 3-24.

53. Fishburn, P.C. Additive utilities with finite sets: Applications in the management sciences. Nav. Res. Logist. Q. 1967, 14, 1-13. [CrossRef]

54. Polatidis, H.; Haralambopoulos, D.A.; Munda, G.; Vreeker, R. Selecting an Appropriate Multi-Criteria Decision Analysis Technique for Renewable Energy Planning. Energy Sources Part B Econ. Plan. Policy 2006, 1, 181-193. [CrossRef]

55. Van de Geer, J.P. Some Aspects of Minkowski Distance; Leiden University: Leiden, The Neitherlands, 1995.

56. Roberts, R.; Goodwin, P. Weight approximations in multi-attribute decision models. J. Multi-Criteria Decis. Anal. 2002, 11, $291-303$. [CrossRef]

57. Edwards, W. How to Use Multiattribute Utility Measurement for Social Decisionmaking. IEEE Trans. Syst. Man Cybern. 1977, 7, 326-340. [CrossRef]

58. Stella, G.A. Il castello in rovina dimenticato da Milano. Corr. Della Sera 2011. Available online: https://milano.corriere.it/milano/ notizie/cronaca/11_ottobre_17/stella-castello-1901843477011.shtml (accessed on 18 March 2021).

59. Bellini, A. Conservazione e fruizione del patrimonio architettonico: Un problema etico. Territorio 2013, 64, 9-17.

60. Fiorani, D.; Kealy, L.; Musso, S.F. Conservation/Adaptation. Keeping Alive the Spirit of the place. Adaptive reuse of Heritage with Symbolic Value; Fiorani, D.K., Loughlin, M., Stefano, P., Bie, H., Claudine Van Cleempoel, K., Eds.; EAAE: Hasselt, Belgium, 2017; ISBN 9782930301655.

61. Torsello, B.P. Che cos' è il restauro? In Che cos'è il Restauro? Nove Studiosi a Confronto; Marsilio, Ed.; Marsilio: Venezia, Italy, 2005; pp. 9-17, 53 -56. ISBN 978-88-317-8645-4.

62. Borgatti, S. Castelli Fratelli. Un Curioso Tentativo di Salvataggio; La Memoria del Mondo: Milan, Italy, 2011 ; ISBN 8895898575. 
63. Del Tredici, F.; Rossetti, E. Percorsi Castellani: Da Milano a Bellinzona: Guida ai Castelli del Ducato; Edizioni, N., Ed.; Castelli del ducato: Parma, Italy, 2012; ISBN 8896451027, 9788896451021.

64. Della Torre, S. A coevolutionary approach to the reuse of built cultural heritage. In Proceedings of the in Atti del XXXV Convegno internazionale "Il Patrimonio Culturale in mutamento. Le sfide dell'uso", Bressanone, Italy, 7-9 July 2019; pp. 25-34.

65. Musso, S. Recupero e Restauro Degli Edifici Storici. Guida Pratica al Rilievo e alla Diagnostica; EPC Libri: Rome, Italy, 2004; ISBN 8881843285.

66. Sulfaro, N. L'Architettura Come Opera Aperta. Il tema dell'uso nel Progetto di Conservazione; ArcHistoR extra 2: Reggio Calabria, Italy, 2018; ISBN 978-88-85479-02-9.

67. Istituto Superiore di Sanità Conclusa L'indagine Sulle Rsa-ISS. Available online: https:/ /www.iss.it/covid-19-primo-piano/- / asset_publisher/yX1afjCDBkWH/content/conclusa-1-indagine-sulle-rsa (accessed on 18 March 2021).

68. Rollino, L. Progettare e Adeguare le RSA in Epoca Post Covid: Aspetti Architettonici e Impiantistici per Assicurare Salubrità. Available online: https://www.ingenio-web.it/27184-progettare-e-adeguare-le-rsa-in-epoca-post-covid-19 (accessed on 18 March 2021).

69. Anderson, D.C.; Grey, T.; Kennelly, S.; O’Neill, D. Nursing Home Design and COVID-19: Balancing Infection Control, Quality of Life, and Resilience. J. Am. Med. Dir. Assoc. 2020, 21, 1519-1524. [CrossRef]

70. Ministero Dell'istruzione Didattica a Distanza. Available online: https://www.istruzione.it/coronavirus/didattica-a-distanza_ rai.html (accessed on 19 March 2021).

71. Università dEgli Studi di Milano Facoltà di Scienze Agrarie e Alimentari. Available online: https://www.unimi.it/it/corsi/ facolta-e-scuole/scienze-agrarie-e-alimentari (accessed on 19 March 2021).

72. Federazione Italiana dei Pubblici Esercizi Crolla L'occupazione nei Pubblici Esercizi, Persi 243mila Posti di Lavoro. FipeConfcommercio: “Colpiti Soprattutto i Giovani”. Available online: https://www.fipe.it/comunicazione/note-per-la-stampa/ item/7685-crolla-1-occupazione-nei-pubblici-esercizi-persi-243mila-posti-di-lavoro-fipe-confcommercio-colpiti-soprattutto-igiovani.html (accessed on 19 March 2021).

73. il Sole 24 Focus di Settore per far Ripartire L'italia PMI, la Ripresa Post Covid. Available online: https:/ minisiti.ilsole24ore.com/ focuspmi/wp-content/uploads/pdf/Focus\%20PMI-Report\%20complessivo.pdf (accessed on 19 March 2021).

74. Dell'Anna, F.; Vergerio, G.; Corgnati, S.P.; Mondini, G. A new price list for retrofit intervention evaluation on some archetypical buildings. Valorie Valutazioni 2019, 22, 3-17.

75. Genio Civile Prezziari Tipologici; DEI: Rome, Italy, 2019; ISBN 9788831284035.

76. Riabacke, M.; Danielson, M.; Ekenberg, L. State-of-the-Art Prescriptive Criteria Weight Elicitation. Adv. Decis. Sci. 2012, 2012, 1-24. [CrossRef]

77. Gamboa, G.; Munda, G. The problem of windfarm location: A social multi-criteria evaluation framework. Energy Policy 2007, 35, 1564-1583. [CrossRef]

78. Barron, F.H.; Barrett, B.E. The efficacy of SMARTER-Simple Multi-Attribute Rating Technique Extended to Ranking. Acta Psychol. (Amst). 1996, 93, 23-36. [CrossRef]

79. Roy, B. Multicriteria Methodology for Decision Aiding. In Nonconvex Optimization and Its Applications; Springer US: Boston, MA, USA, 1996; Volume 12, ISBN 978-1-4419-4761-1. 